\title{
DESKRIPSI PELAKSANAAN PEMBERANTASAN SARANG NYAMUK (PSN) DEMAM BERDARAH DENGUE (DBD) DI KELURAHAN KARANGPUCUNG KECAMATAN PURWOKERTO SELATAN KABUPATEN BANYUMAS TAHUN 2014
}

\author{
Ratna Pramurditya*), Arif Widyanto, S.Pd., M.Si. $\left.{ }^{* *}\right)$
}

Abstract

\begin{abstract}
DHF incidence rate increases caused by the lack of clean and healthy behaviors. DHF is caused by dengue virus by mosquitoes of the genus Aedes (Aedes aegypti and Aedes albopictus). The highest number of DHF at 2013 in Banyumas regency is South of Purwokerto district (92 cases). Karangpucung village (21 cases) the highest DHF. Mosquito nest eradication action DHF include survey of mosquito larvae was done in Karang pucung village but the larvae-free rate (ABJ) not yet to reach the target (94.09\%), so the researcher wanted to discover the implementation of mosquito nest eradication dengue hemorrhagic fever in Karang pucung village South of Purwokerto district Banyumas regency year 2014.

Type research is observation with descriptive analysis qualitative survey approach which provides an overview the implementation of mosquito nest eradication DHF in Karang pucung village. Sample from 98 families head in 12 RW at the Karangpucung village by Systematic Random Sampling.

The implementation of mosquito nest eradication DHF in Karangpucung Village done 95 families head (97\%). RW 1 (39\%) and RW 2 (29\%) the lowest implementation of mosquito nest eradication, RW $9(66 \%)$ and RW 7 (63\%) the highest implementation of mosquito nest eradication. Survey motion plus $3 \mathrm{M}$ low of practice was to use a mosquito net (4\%), the larvae-eating fish (6\%), the use of wire gauze on the ventilation holes (12\%), sowing abate (17\%). The survey result, larvae in Karangpucung village the larvae-free rate $(A B J)$ not eligible (79\%), $\mathrm{HI}$ are not eligible (21\%), $\mathrm{Cl}$ does not qualify (5\%), BI eligible (23\%). RW 2 and 4 have the lowest $A B J$ and $\mathrm{HI}, \mathrm{Cl}, \mathrm{BI}$ highest, in accordance with the highest number of dengue cases in RW 4 (5 cases) and RW 2 (1 case).

Researcher conclusion is the implementation of mosquito nest eradication dengue hemorrhagic fever in Karangpucung Village, not all of the people active of mosquito nest eradication dengue hemorrhagic fever in the movement $3 \mathrm{M}$ plus. Many mosquito larvae still found so mosquito nest eradication target not reach ( $A B J \geq 95 \%$ ). Community and cadres suggested more active in the implementation of mosquito nest eradication.
\end{abstract}

Reading list : 29 (1992-2013)

Keyword : : Mosquito nest eradication dengue hemorrhagic fever

Classification :-

*) Alumni Mahasiswa Jurusan Kesehatan Lingkungan Purwokerto

${ }^{* *}$ ) Dosen Jurusan Kesehatan Lingkungan Purwokerto

\section{PENDAHULUAN}

A. Latar Belakang

Rencana Pembangunan Jangka Panjang Bidang Kesehatan (RPJP-K) adalah rencana pembangunan nasional di bidang kesehatan yang merupakan penjabaran dari RPJPN Tahun 2005-2025, dalam bentuk dasar, visi, misi, arah dan kebutuhan sumber daya pembangunan nasional di bidang kesehatan untuk masa 20 tahun ke depan. Berbagai penyakit menular masih merupakan masalah kesehatan masyarakat. Incidence Rate penyakit demam berdarah (DBD) meningkat tahun demi tahun, yang disebabkan penanganan lingkungan kurang baik yang berkaitan dengan masih kurangnya perilaku hidup bersih dan sehat. (Depkes RI, 2009, h.1 dan 12)

Demam Berdarah Dengue (DBD) adalah penyakit demam akut yang disebabkan virus Dengue. Penyakit ini ditemukan di daerah tropis dan disebarkan kepada manusia oleh nyamuk genus Aedes, misalnya Aedes aegypti dan Aedes albopictus. Penularan DBD dapat terjadi di dalam atau di luar rumah.

Kejadian DBD masih ditemukan hingga saat ini, salah satu penyebabnya adalah kegiatan pemberantasan vektor DBD yang kurang maksimal. 
Pemberantasan vektor DBD yang tidak dilakukan sesuai anjuran seperti pemeriksaan jentik berkala, fogging serta PSN menjadi faktor penyebab masih ditemukannya kasus DBD. Menurut penelitian Sri Wahyuni (Tahun 2013) menunjukkan cakupan ABJ > 95\%, masih tetap ada kemungkinan timbulnya tempat perkembangbiakan jentik Aedes aegypti.

Penyakit DBD perlu mendapatkan perhatian serius dari semua pihak, mengingat jumlah kasusnya cenderung masih dapat ditemukan setiap tahunnya. Indonesia masih menjadi sarang kasus demam berdarah. Hingga pertengahan bulan Juli 2013, kasus demam berdarah terjadi di 31 provinsi dengan penderita 48.905 orang, 376 di antaranya meninggal dunia.(Tempo, 26 Juli 2013)

Kejadian DBD di Kabupaten Banyumas masih dapat ditemukan, berdasarkan data Dinas Kesehatan Kabupaten Banyumas dari tahun 2009-2013 masih ditemukan kasus DBD. Angka kejadian DBD pada tahun 2009 terdapat 382 kasus (5 orang meninggal) dengan IR 15/100.000 dan CFR $1,31 \%$. Kasus DBD meningkat pada tahun 2010 yaitu 696 kasus (7 orang meninggal) dengan IR 42,6/100.000 dan CFR 1,01\%. Tahun 2011 sebanyak 201 kasus(3 orang meninggal) dengan IR 12,31/100.000 dan CFR 1,49 \%. Tahun 2012 mengalami penurunan tercatat 200 kasus (4 orang meninggal) dengan IR 11,78/100.000 dan CFR 2,01\%.Tahun 2013 terjadi kenaikan kasus, tercatat 543 kasus (4 orang meninggal) dengan IR 32,14/100.000 dan CFR 0,74\%. (Laporan Dinas Kesehatan Kabupaten Banyumas, 2013)

Wilayah Kecamatan di Kabupaten Banyumas dengan jumlah kasus DBD tertinggi tahun 2013 adalah Kecamatan Purwokerto Selatan yaitu sebanyak 92 kasus. Berdasarkan data Puskesmas Purwokerto Selatan kasus DBD tahun 2009-2013 masih ditemukan. Kasus DBD tercatat pada tahun 2009 sebanyak 47 kasus, kemudian naik pada tahun 2010 sebanyak 126 kasus. Angka kejadian kasus mengalami penurunan pada tahun 2011 sebanyak 67 kasus, kemudian turun menjadi 31 kasus pada tahun 2012. Kasus DBD mengalami kenaikan pada tahun 2013 sebanyak 92 kasus. Wilayah yang paling tinggi kasus DBD adalah Kelurahan Karangpucung yang merupakan salah satu desa endemis DBD tahun 2013 dengan 21 kasus DBD. Tindakan pengendalian vektor telah dilakukan seperti Pemberantasan Sarang Nyamuk (PSN) Demam Berdarah Dengue (DBD) termasuk kegiatan survei jentik nyamuk di Kelurahan Karangpucung Kecamatan Purwokerto Selatan namun ABJ pada tahun 2013 masih 94,09\%.

Berdasarkan pertimbangan diatas penulis terdorong untuk mengadakan penelitian dengan judul "Deskripsi Pelaksanaan Pemberantasan Sarang Nyamuk (PSN) Demam Berdarah Dengue (DBD) di Kelurahan Karangpucung Kecamatan Purwokerto Selatan Kabupaten Banyumas Tahun 2014".

\section{B. Perumusan Masalah}

Wilayah Kelurahan Karangpucung yang kasus DBD tertinggi sebanyak 21 kasus yang merupakan desa endemis DBD tahun 2013. Tindakan pengendalian vektor telah dilakukan seperti PSN DBD termasuk kegiatan survei jentik nyamuk namun $A B J$ pada tahun 2013 masih 94,09\%, belum mencapai target $A B J \geq 95 \%$, maka perlu dilakukan penelitian untuk mengetahui kondisi yang sebenarnya tentang pelaksanaan PSN DBD di Kelurahan Karangpucung.

\section{Tujuan Penelitian}

1. Tujuan umum

Mengetahui Pelaksanaan

Pemberantasan Sarang Nyamuk (PSN)

Demam Berdarah Dengue (DBD) di

Kelurahan Karangpucung, Kecamatan Purwokerto Selatan, Kabupaten Banyumas Tahun 2014.

2. Tujuan khusus

a. Mendeskripsikan praktik gerakan 3M plus (menguras, menutup rapat tempat penampungan air, mengubur / meyingkirkan barang-barang bekas plus mengganti air vas bunga, minuman burung, memperbaiki talang air, menutup lubang-lubang pada potongan bambu atau pohon, melakukan abatisasi, mempelihara ikan pemakan jentik, memasang kawat kasa, tidak menggantung pakaian, tidur menggunakan kelambu, menggunakan obat nyamuk) di Kelurahan Karangpucung, Kecamatan Purwokerto Selatan, Kabupaten Banyumas Tahun 2014.

b. Menghitung Angka Bebas Jentik (ABJ), Container Index (Cl), House Index (HI) dan Breteu Index (BI) di 
Kelurahan

Karangpucung,

Kecamatan Purwokerto Selatan, Kabupaten Banyumas Tahun 2014.

c. Membandingkan Angka Bebas Jentik $(\mathrm{ABJ})$, Container Index (Cl), House Index (HI) dan Breteu Index (BI) dengan standar atau peraturan yang berlaku (Depkes RI Tahun 1995 untuk ABJ dan WHO Tahun 2007 untuk $\mathrm{Cl}, \mathrm{HI}, \mathrm{BI}$ )

\section{Manfaat Penelitian}

1. Manfaat bagi masyarakat

Penelitian ini diharapkan dapat memberikan manfaat bagi masyarakat mengenai cara pengendalian vektor demam berdarah yang tepat agar kejadian DBD dapat berkurang jumlahnya.

2. Manfaat bagi pemerintah

Bagi dinas Kabupaten Banyumas penelitian ini dapat digunakan untuk menentukan suatu kebijakan mengenai kejadian DBD yang terjadi di wilayah Kelurahan Karangpucung, Kecamatan Purwokerto Selatan.

3. Manfaat bagi almamater

Sebagai masukan ilmu pengetahuan tentangPemberantasan Sarang Nyamuk (PSN) Demam Berdarah Dengue (DBD).

4. Manfaat bagi peneliti

Memberikan tambahan pengetahuan dan pengalaman mengenai
Pemberantasan Sarang Nyamuk (PSN) Demam Berdarah Dengue DBD.

\section{METODE PENELITIAN}

\section{A. Kerangka Pikir}

1. Komponen penyusun

a. Pencegahan DBD

Upaya yang dilakukan agar manusia tidak terjangkit penyakit DBD.

b. PSN DBD

Tindakan yang dilakukan dalam upaya pencegahan dan pemberantasan penyakit demam berdarah dengue dengan kegiatan 3M Plus.

c. Survei jentik Survei jentik dilakukan dengan cara pemeriksaan terhadap semua tempat atau genangan air yang tidak berhubungan langsung dengan tanah dan dimungkinkan sebagai tempat perkembangbiakan nyamuk Aedes dengan menghitung ukuran jentik seperti $\mathrm{ABJ}, \mathrm{HI}, \mathrm{Cl}$, dan $\mathrm{BI}$.

d. Pengendalian vektor

Tindakan untuk mencegah gigitan nyamuk Aedes sp terhadap manusia dengan cara yang ada pada tindakan gerakan 3M plus seperti memasang kawat kasa pada lubang ventilasi, tidur menggunakan kelambu dan menggunakan obat nyamuk.

2. Gambar kerangka pikir

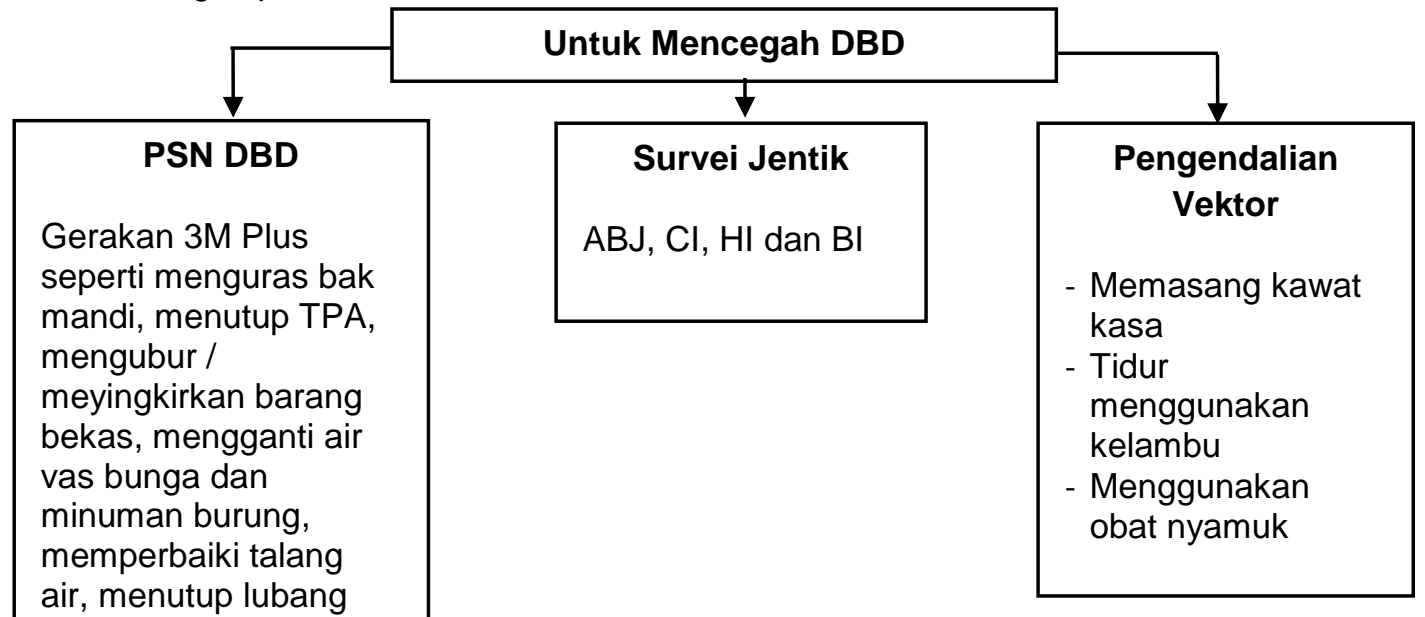

pada pohon, abatisasi,

mempelihara ikan

pemakan jentik, tidak

menggantung pakaian.

Gambar 3.1

Kerangka Pikir 


\section{B. Jenis Penelitian}

Jenis penelitian ini adalah observasional dengan analisis deskriptif pendekatan survei kualitatif yaitu memberikan gambaran mengenai pelaksanaan Pemberantasan Sarang Nyamuk (PSN) Demam Berdarah Dengue (DBD).

\section{Ruang Lingkup}

1. Waktu

Secara terperinci waktu penelitian terbagi dalam tiga tahap yaitu:
a. Tahap persiapan : September 2013 - Februari 2014
b. Tahap pelaksanaan : Mei-Juni 2014
c. Tahap penyelesaian: Juni 2014

2. Lokasi

Lokasi penelitian ini dilakukan di Kelurahan Karangpucung, Kecamatan Purwokerto Selatan, Kabupaten Banyumas.

3. Materi

Materi penelitian ini mengenai pengendalian vektor penyakit DBD dengan mengamati Pelaksanaan Pemberantasan Sarang Nyamuk (PSN) Demam Berdarah Dengue (DBD) di Kelurahan Karangpucung, Kecamatan Purwokerto Selatan, Kabupaten Banyumas Tahun 2014 yang meliputi praktik gerakan 3M Plus, survei jentik dengan menghitung $\mathrm{ABJ}, \mathrm{Cl}, \mathrm{HI}, \mathrm{BI}$, dan membandingkan $\mathrm{ABJ}$, $\mathrm{Cl}$, $\mathrm{HI}$ dan $\mathrm{BI}$ dengan standar atau peraturan yang berlaku.

\section{Populasi dan Sampel}

1. Populasi

Keseluruhan Kepala Keluarga (KK) di Kelurahan Karangpucung yang berjumlah 3.756 KK dengan jumlah seluruh RW sebanyak 12 RW.

2. Sampel

Perhitungan sampel menggunakan rumus Slovin dengan jenis sampling yang digunakan yaitu Systematic Random Sampling.

Rumus Slovin :

$$
\begin{aligned}
& \mathrm{n}=\frac{\mathrm{N}}{1+\mathrm{Nd}^{2}} \\
& \text { Keterangan: } \\
& \mathrm{n}=\text { Sampel } \\
& \mathrm{N}=\text { Populasi } \\
& \mathrm{d}=\text { Besarnya penyimpangan yang masih }
\end{aligned}
$$

bisa ditolerir, ketelitian, kecermatan, tergantung peneliti $(d=0,1 ; 0,05 ; 0,01)$

$$
\begin{aligned}
\mathrm{n} & =\frac{3.756}{1+3.756(0,1)^{2}} \\
& =\frac{3.756}{38,65} \\
& =98 \\
\text { Angka kelipatan } & =\frac{\mathrm{N}}{\mathrm{n}} \\
& =\frac{3.756}{98} \\
& =38
\end{aligned}
$$

Besar sampel yang digunakan sebesar $98 \mathrm{KK}$ yang tersebar pada $12 \mathrm{RW}$ di Kelurahan Karangpucung dengan cara Systematic Random Sampling Angka undian yang keluar adalah 471 , sehingga nomer sampel pertama adalah 471 . Sampel kedua didasarkan pada kelipatan yang sudah dihitung yaitu 38 , sehingga didapatkan jumlah sampel di RW 1 (11 KK), RW 2 (8 KK), RW 3 (7 KK), RW 4 (10 KK), RW 5 (7 KK), RW 6 (10 KK), RW 7 (11 KK), RW 8 (11 KK), RW 9 (7 KK), RW 10 (5 KK), RW 11 (7 KK), dan RW 12 (4 KK).

\section{E. Pengumpulan Data}

1. Jenis Data

a. Data umum

Data umum dalam penelitian ini adalah batas wilayah geografis, topografi dan demografi Kelurahan Karangpucung (jumlah penduduk menurut umur dan jenis kelamin, pendidikan, pekerjaan).

b. Data khusus

Data khusus dalam penelitian ini adalah pelaksanaan PSN (3M Plus dan survei jentik nyamuk yang meliputi $\mathrm{ABJ}, \mathrm{Cl}, \mathrm{HI}$ dan $\mathrm{BI}$ ).

2. Sumber data

a. Data Primer

Data primer diperoleh secara langsung melalui:

1) Wawancara dengan responden mengenai pelaksanaan PSN yang telah dilakukan.

2) Hasil pengamatan melalui survei jentik nyamuk yang dilaksanakan di Kelurahan Karangpucung.

b. Data sekunder

Data yang diperoleh berasal dari kantor Kelurahan Karangpucung, Puskesmas Purwokerto Selatan dan Dinas Kesehatan Kabupaten Banyumas.

3. Cara pengumpulan data

a. Wawancara dilakukan peneliti dengan cara berdialog langsung dengan responden. 
b. Observasi dengan cara pengamatan langsung terhadap obyek penelitian.

4. Instrumen/alat pengumpul data

Dalam penelitian ini, instrument yang digunakan untuk mengumpulkan data berupa kuesioner.

\section{F. Analisis Data}

Analisis data yang digunakan adalah analisis univariat dengan menggunakan persentase mengenai praktik gerakan $3 \mathrm{M}$ Plus secara keseluruhan pada $98 \mathrm{KK}$ di Kelurahan Karangpucung, membandingkan hasil hitungan mengenai $\mathrm{ABJ}, \mathrm{Cl}, \mathrm{HI}$ dan $\mathrm{BI}$ dengan standar atau peraturan yang ada dan penyajian data yang menggunakan tabel dan narasi.

\section{HASIL}

\section{A. Gambaran Umum Kelurahan Karangpucung Kecamatan Purwokerto Selatan Kabupaten Banyumas}

1. Keadaan Geografis

Kelurahan Karangpucung merupakan kelurahan yang ada di Kecamatan Purwokerto Selatan, berdasarkan data dari Badan Pusat Statistik (BPS) Kabupaten Banyumas luas wilayah Kelurahan Karangpucung 156,00 Ha. Wilayah Kelurahan Karangpucung terdiri dari tanah persawahan seluas $39,10 \mathrm{Ha}$, pekarangan/bangunan seluas $109,55 \mathrm{Ha}$, kolam seluas $4,65 \mathrm{Ha}$, hutan rakyat seluas $1,14 \mathrm{Ha}$, lain-lain seluas 4,56 $\mathrm{Ha}$. Kelurahan Karangpucung terbagi menjadi 12 RW dan 56 RT. Batas wilayah Kelurahan Karangpucung adalah sebagai berikut:

Sebelah Timur : Kelurahan Purwokerto Kulon

Sebelah Barat : Kelurahan Tanjung Sebelah Utara : Kelurahan Kranji

Sebelah Selatan: Kelurahan Karang Klesem

2. Keadaan Demografi

a. Jumlah Penduduk Menurut Jenis Kelamin

Jumlah penduduk keseluruhan di Kelurahan Karangpucung berdasarkan data profil Kelurahan Karangpucung sebanyak 13.318 jiwa dengan jumlah penduduk laki-laki sebanyak 6.787 jiwa dan jumlah penduduk perempuan 6.531 jiwa.

\section{b. Jumlah Penduduk Menurut Kelompok} Umur

Jumlah penduduk menurut kelompok umur yaitu sebagai berikut:

Tabel 4.1 :Jumlah Penduduk Menurut Kelompok Umur di Kelurahan Karangpucung Tahun 2014

\begin{tabular}{|r|l|r|r|}
\hline No & $\begin{array}{c}\text { Kelompok Umur } \\
\text { (Tahun) }\end{array}$ & \multicolumn{1}{|c|}{$\begin{array}{c}\text { Jumlah Penduduk } \\
\text { (Orang) }\end{array}$} & $\begin{array}{r}\% \\
\text { Penduduk }\end{array}$ \\
\hline 1 & $0-4$ & 897 & 6,73 \\
\hline 2 & $5-9$ & 1.087 & 8,15 \\
\hline 3 & $10-14$ & 1.073 & 8,05 \\
\hline 4 & $15-19$ & 869 & 7,27 \\
\hline 5 & $20-24$ & 1.028 & 7,71 \\
\hline 6 & $25-29$ & 1.175 & 8,81 \\
\hline 7 & $30-34$ & 1.364 & 10,23 \\
\hline 8 & $35-39$ & 1.142 & 8,57 \\
\hline 8 & $40-44$ & 960 & 7,20 \\
\hline 10 & $44-49$ & 861 & 6,46 \\
\hline 11 & $50-54$ & 760 & 5,70 \\
\hline 12 & $55-59$ & 674 & 5,06 \\
\hline 13 & $60-64$ & 493 & 3,70 \\
\hline 14 & $65-69$ & 287 & 2,15 \\
\hline 15 & $70-74$ & 234 & 1,76 \\
\hline 16 & $75-79$ & 162 & 1,22 \\
\hline 17 & $80-84$ & 90 & 0,68 \\
\hline 18 & $85-89$ & 51 & 0,38 \\
\hline 19 & $90-94$ & 11 & 0,08 \\
\hline 20 & 85 ke atas & 12 & 0,09 \\
\hline \multicolumn{2}{|c|}{ Jumlah } & 13.318 & 100,00 \\
\hline Sumber $:$ Profil Kelurahan Karangpucung Tahun 2014 \\
\hline
\end{tabular}

Jumlah penduduk terbesar menurut kelompok umur yaitu pada rentang umur 30-34 tahun dengan jumlah 1.364 orang dan jumlah penduduk terkecil yaitu umur 90-94 tahun dengan jumlah 11 orang.

c. Jumlah Penduduk Menurut Pendidikan Jumlah penduduk menurut pendidikan adalah sebagai berikut:

Tabel 4.2: Jumlah Penduduk Menurut Pendidikan di Kelurahan Karangpucung Tahun 2014

\begin{tabular}{|c|c|c|c|c|}
\hline \multirow{2}{*}{ No } & \multirow{2}{*}{ Janjang Parididikan } & \multicolumn{2}{|c|}{ Jumlah Siswa } & \multirow{2}{*}{ | Jutritath } \\
\hline & & Laki-Laki & Parempuati & \\
\hline 1 & Usta tidakbalum sekolath & 1.124 & 1.082 & 2.216 \\
\hline 2 & Belum tartat SD & 698 & 721 & 1.409 \\
\hline
\end{tabular}




\begin{tabular}{|c|c|c|c|c|}
\hline \multirow{2}{*}{ No } & \multirow{2}{*}{ Jenijang Pendididikan } & \multicolumn{2}{|c|}{ Jumlath Siswa } & \multirow{2}{*}{ Jumilath } \\
\hline & & Laki-Laki & Parempuan & \\
\hline 3 & Tamat 50 & 1.275 & 1.456 & 2731 \\
\hline 4 & Tamat SMP/Saderajat & 895 & 928 & 1.813 \\
\hline 5 & Tamiat SMA/Saderajä & 1.938 & 1.654 & 3.590 \\
\hline$\theta$ & Diplomia lill & 35 & 49 & 84 \\
\hline 7 & Diplontia ||| & 156 & 176 & 392 \\
\hline g & Dplomita |VSirata 1 (51) & 596 & 433 & 969 \\
\hline 8 & Strata || (S2) & 54 & 23 & 77 \\
\hline 10 & Strala III (53) & 3 & 2 & 5 \\
\hline & Jurrilan Total & & & 13.318 \\
\hline
\end{tabular}

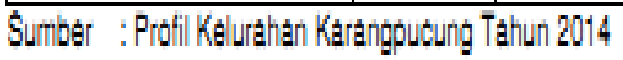

Jumlah penduduk terbesar pada pendidikan tamat SMA/ Sederajat yaitu 3.590 orang dan jumlah terkecil pada pendidikan Strata III (S3) yaitu 5 orang.

d. Mata Pencaharian Penduduk

Mata pencaharian penduduk dapat dilihat pada tabel berikut:

Tabel 4.3 : Mata Pencaharian Penduduk di Kelurahan Karangpucung Tahun 2014

\begin{tabular}{|c|c|c|c|c|c|}
\hline \multirow{2}{*}{$\mathrm{No}$} & \multirow{2}{*}{ Jenils Pekeriatan } & \multicolumn{2}{|c|}{ Jumlath } & \multirow{2}{*}{$\begin{array}{c}\text { Jumlah } \\
\text { Kesturuhthin }\end{array}$} & \multirow{2}{*}{$\%$} \\
\hline & & Lakil-Laki & Peraringualin & & \\
\hline 1 & Aptotaker & 1 & 4 & 5 & 0,04 \\
\hline 2 & Bidan & . & 6 & $B$ & 0,05 \\
\hline 3 & Buruh hatrianlespats & 1.008 & 184 & 1.182 & 8,85 \\
\hline 4 & Buruh tarnak & 1 & . & 1 & 0,01 \\
\hline 5 & Buruh tatri & 1 & . & 1 & 0,01 \\
\hline 6 & Dokter & 2 & 8 & 10 & 0,08 \\
\hline 7 & Dobsesin & 12 & 10 & 22 & 0,17 \\
\hline 8 & Gưu & 30 & 85 & 115 & 0,86 \\
\hline 8 & Iridustiti & 1 & 2 & 3 & 0,02 \\
\hline 10 & BUMD & 6 & 3 & 8 & 0,07 \\
\hline 11 & BUMN & 57 & 20 & 77 & 0,58 \\
\hline 12 & Kanyawan hantiorer & 23 & 22 & 45 & 0,34 \\
\hline 13 & Kanawan Swatia & 1.351 & 614 & 1.965 & 14,75 \\
\hline 14 & Konisultan & 1 & 1 & 2 & 0,02 \\
\hline 15 & Konitruksi & 10 & 1 & 11 & 0,08 \\
\hline 16 & Meskanilik & 15 & . & 15 & 0,11 \\
\hline
\end{tabular}

\begin{tabular}{|c|c|c|c|c|c|}
\hline \multirow{2}{*}{$\mathbf{N a}$} & \multirow{2}{*}{ Janis Poworyn } & \multicolumn{2}{|c|}{ Jum|ah } & \multirow{2}{*}{ Jumbirth } & \multirow{2}{*}{$\gamma$} \\
\hline & & Ant.ak & Parampuar & & \\
\hline 17 & Naitans & 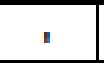 & 1 & 1 & 0,01 \\
\hline $1:$ & Putur & 1 & 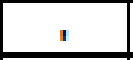 & 1 & 0.1 \\
\hline $1:$ & Podayarg & 13. & Itis & HE & 1,8 \\
\hline 21 & Ponua Nogar Gal Pvis & 218 & 12 & 24 & $2 t 5$ \\
\hline 21 & Powa: & 1 & 1 & 1 & 0.01 \\
\hline 2 & \begin{tabular}{|l|} 
Parmbantu Rumeh Targa: \\
\end{tabular} & 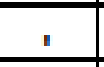 & 3 & E & 0.27 \\
\hline 2 & Panth bustra & 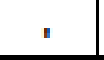 & 1 & 1 & 0.01 \\
\hline 24 & Punzia mathat: & 1 & 4 & 1 & 0,04 \\
\hline d & POA & 21 & 1 & 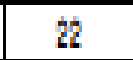 & 0,17 \\
\hline at & Purdah & 1 & 1 & 2 & 0,02 \\
\hline 77 & Pongana & 1 & " & 1 & 0.01 \\
\hline a & Parsiun & 211 & 2 & 210 & 228 \\
\hline 8 & Penghe dus & 2 & 1 & 2 & 0,2 \\
\hline 81 & Protsungan & 2 & 37 & Es & D. \\
\hline 81 & PranilPaknobur & 34 & 15 & 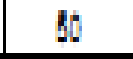 & Q.3B \\
\hline 2 & Prama & 2 & 1 & 2 & 0,2 \\
\hline 8 & Prameta asน & 1 & 1 & 1 & 0.01 \\
\hline 34 & Phakidar & $n$ & 1 & 1 & 0.01 \\
\hline II & Guniman & 1 & I & 1 & 0.1 \\
\hline 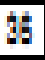 & Gapi & 72 & 1 & 72 & 0.4 \\
\hline 37 & Taso & 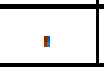 & 1 & 1 & 0.01 \\
\hline 8 & $\mathrm{TN}$ & 16 & 1 & 18 & 0.14 \\
\hline 8 & Tranmonth & 36 & 1 & $y$ & 02 \\
\hline 40 & Tukan: ba:. & 3 & 1 & $\Delta$ & 0.25 \\
\hline 41 & Tuhan; aku" & 1 & 1 & 1 & 0.01 \\
\hline 42 & Futum: ati: & 2 & 21 & 48 & 02 \\
\hline 43 & Tuhanghay & 72 & . & 7 & 0,14 \\
\hline 44 & Tukang las & 4 & 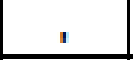 & 4 & a.t. \\
\hline 4 & $\operatorname{Ln}:$ & 1 & 1 & 1 & 0.1 \\
\hline 45 & Watriman & 1 & . & 1 & 0.01 \\
\hline 47 & Wrawasta & 81 & It: & 74 & A. \\
\hline $4:$ & Pwalaintasina & 1283 & 1,19 & 2418 & 11,15 \\
\hline 49 & Margurus Aumah Taraz & 1 & 236 & 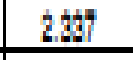 & $17, \mathbb{H}$ \\
\hline 10 & Pouma: & 1 & 10 & 11 & A.t. \\
\hline$\$ 1$ & Tan aniari2 & & & $2 \mathrm{en}$ & 2,17 \\
\hline & Jurah Teal & & & 13.818 & 160 \\
\hline
\end{tabular}


Berdasarkan tabel tersebut dapat diketahui mata pencaharian penduduk yang terbesar di Kelurahan Karangpucung adalah tidak bekerja dengan jumlah 2.952 orang dan mata pencaharian yang jumlahnya terkecil adalah wartawan, ustad, tukang cukur, tabib, seniman, physikiater, promotor acara, pengacara, penata busana, pelaut, pastur, notaris, buruh tani, buruh ternak dengan jumlah masingmasing 1 orang.

3. Keadaan Topografi

Keadaan topografi berdasarkan data dari Badan Pusat Statistik Kabupaten Banyumas, Kelurahan Karangpucung terletak pada ketinggian $74 \mathrm{~m}$ dari permukaan laut. Curah hujan pada wilayah Kelurahan Karangpucung $99 \mathrm{~mm} / \mathrm{tahun}$ dengan suhu rata-rata $26,3 \stackrel{\circ}{\mathrm{C}}$.

\section{B. Data Khusus}

1. Pelaksanaan Pemberantasan Sarang Nyamuk (PSN) Demam Berdarah Dengue (DBD)

Kelurahan Karangpucung telah melakukan kegiatan PSN DBD, hal tersebut dilakukan setiap hari Jum'at dan Minggu. Kegiatan bersih-bersih lingkungan dengan kerja bakti warga dilakukan setiap hari Jum'at dan kegiatan survei jentik nyamuk yang di koordinir oleh kader yang ada setiap RW dilakukan setiap hari Minggu. Pelaksanaan PSN DBD telah dijadwalkan dari pihak kelurahan untuk dilakukan oleh seluruh RW yang ada di wilayah Kelurahan Karangpucung. Jumlah seluruh kader/jumantik di Kelurahan Karangpucung 149 kader yang tersebar pada masing-masing dawis, namun tidak semuanya aktif. Kader PSN DBD tersebut telah diberi pelatihan oleh Dinas Kesehatan Kabupaten Banyumas. Ketersediaan sarana/peralatan yang dibutuhkan dalam kegiatan survei jentik seperti senter, blanko laporan telah tersedia, namun jumlahnya terbatas. Penyululuhan mengenai Demam Berdarah Dengue dan PSN DBD telah dilakukan pada pertemuan PKK atau dawis di setiap RW.

Survei mengenai Pelaksanaan Pemberantasan Sarang Nyamuk (PSN) Demam Berdarah Dengue (DBD) telah dilakukan dengan jumlah sampel sebanyak $98 \mathrm{KK}$ yang tersebar pada seluruh RW yang ada di Kelurahan Karangpucung sebanyak 12 RW. Hasil survei tersebut adalah sebagai berikut:

Tabel 4.4 : Hasil Survei Pelaksanaan Pemberantasan Sarang Nyamuk (PSN) Demam Berdarah Dengue (DBD) Di Kelurahan Karangpucung.

\begin{tabular}{|c|c|c|c|c|c|c|c|c|c|c|c|c|c|c|c|}
\hline \multirow{2}{*}{ NO } & \multirow{2}{*}{ VARIABEL KUESIONER } & \multicolumn{12}{|c|}{ RW } & \multirow[b]{2}{*}{ J } & \multirow[b]{2}{*}{$\%$} \\
\hline & & 1 & 2 & 3 & 4 & 5 & 6 & 7 & 8 & 9 & 10 & $11 \mid$ & & & \\
\hline \multicolumn{16}{|c|}{ PELAKSANAAN PSN DBD } \\
\hline 1 & Melakukan PSN & 10 & 7 & & 10 & & $7 \mid 10$ & 11 & 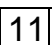 & 7 & 5 & 6 & 4 & 95 & 97 \\
\hline \multicolumn{16}{|c|}{ GERAKAN 3M PLUS } \\
\hline 2 & Menguras bak mand & 7 & 2 & 7 & 9 & 7 & 10 & 11 & 10 & 6 & 5 & 5 & 4 & 59 & 36 \\
\hline 3 & Menutup Tempat Pel & 8 & 5 & 5 & 6 & 5 & 3 & 7 & 11 & 2 & 5 & 4 & 1 & 62 & 91 \\
\hline 4 & $\begin{array}{l}\text { Mengubur atau me } \\
\text { barang bekas }\end{array}$ & 0 & 0 & 7 & 7 & 7 & 10 & 11 & 10 & 5 & 3 & 6 & 4 & 70 & 71 \\
\hline 5 & Menutup lubang $p$ & 0 & 0 & 1 & 1 & 2 & 0 & 4 & 0 & 6 & 2 & 0 & 0 & 16 & 53 \\
\hline 6 & unyai me & 1 & 0 & 3 & 2 & 0 & 0 & 1 & 0 & 1 & 2 & 0 & 0 & 10 & 100 \\
\hline 7 & $\begin{array}{l}\text { Membersihkan tem } \\
\text { sekali }\end{array}$ & 1 & 2 & 1 & 4 & 3 & 4 & 4 & 4 & 1 & 3 & 0 & 0 & 27 & 100 \\
\hline 8 & Menggunakan $c$ & 5 & 4 & 2 & 9 & 6 & 9 & 10 & 9 & 4 & 1 & 3 & 3 & 65 & 66 \\
\hline 9 & Tidur menggunakan kelambu & 0 & 0 & 0 & 1 & 0 & 0 & 1 & 1 & 0 & 0 & 1 & 0 & 4 & 4 \\
\hline 10 & Menggunakan kawat ka & 2 & 0 & 0 & 2 & 1 & 2 & 0 & 0 & 2 & 0 & 1 & 2 & 12 & 12 \\
\hline 11 & $\begin{array}{l}\text { Menaburi abate } 3 \text { bulan sek } \\
\text { penampungan air yang jara }\end{array}$ & 1 & 0 & 1 & 1 & 2 & 4 & 1 & 2 & 4 & 0 & 1 & 0 & 17 & 17 \\
\hline 12 & Mem & 0 & 0 & 0 & 3 & 0 & 1 & 0 & 0 & 1 & 0 & 1 & 0 & 6 & 6 \\
\hline 13 & Tidak & 2 & 1 & 5 & 2 & 2 & 2 & 1 & 3 & 2 & 4 & 3 & 2 & 29 & 30 \\
\hline 14 & Memperbaiki talang air yang rusak & 3 & 4 & 7 & 9 & 7 & 9 & & & 7 & 5 & 5 & 4 & 82 & 84 \\
\hline
\end{tabular}

Pelaksanaan PSN DBD di Kelurahan Karangpucung pada 12 RW yang disurvei menggunakan kuesioner dapat dirinci sebagai berikut: 


\section{a. Pelaksanaan PSN DBD}

PSN DBD yang telah dilakukan oleh masyarakat di Kelurahan Karangpucung adalah suatu tindakan dalam upaya pencegahan dan pemberantasan penyakit demam berdarah dengue dengan kegiatan $3 \mathrm{M}$ plus. Hasil survei Pelaksanaan Pemberantasan Sarang Nyamuk (PSN) Demam Berdarah Dengue (DBD) di Kelurahan Karangpucung secara keseluruhan dapat diketahui dari $98 \mathrm{KK}$ yang disurvei $95 \mathrm{KK}$ telah melakukan PSN DBD dengan persentase $97 \%$, sedangkan $3 \mathrm{KK}$ tidak melakukan PSN DBD di rumahnya dengan persentase $3 \%$. Pelaksanaan PSN DBD pada 12 RW yang disurvai hasil adalah sebagai berikut:

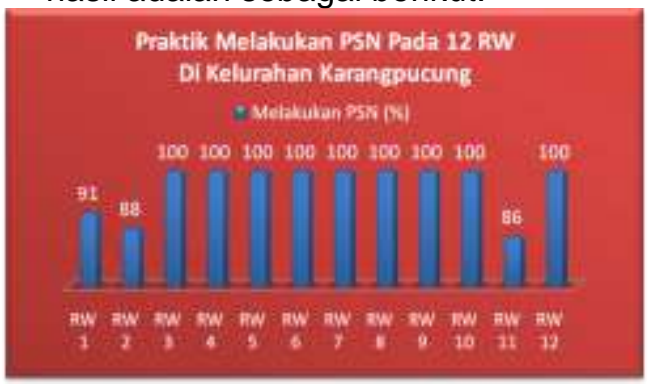

Gambar 4.1

Grafik Pelaksanaan PSN Pada 12 RW Kelurahan Karangpucung

Hasil survei Pelaksanaan Pemberantasan Sarang Nyamuk (PSN) Demam Berdarah Dengue (DBD) pada setiap RW di dapatkan hasil bahwa di RW 1 sebanyak $10 \mathrm{KK}$ melaksanakannya dari 11 KK yang di survei (98\%), RW 2 sebanyak $7 \mathrm{KK}$ melaksanakannya dari 8 KK yang di survei (88\%), RW 11 sebanyak $6 \mathrm{KK}$ melaksanakannya dari 7 KK yang disurvei (86\%). Seluruh masyarakat yang disurvei melaksanakan PSN DBD dengan persentase 100\% yaitu di RW 3 sebanyak 7 KK, RW 4 sebanyak $10 \mathrm{KK}$, RW 5 sebanyak $7 \mathrm{KK}$, RW 6 sebanyak $10 \mathrm{KK}$, RW 7 sebanyak $11 \mathrm{KK}, \mathrm{RW} 8$ sebanyak $11 \mathrm{KK}, \mathrm{RW} 9$ sebanyak $7 \mathrm{KK}$, RW 10 sebanyak $5 \mathrm{KK}$ dan RW 12 sebanyak 4 KK.

b. Gerakan 3M Plus

1) Menguras bak mandi seminggu sekali Hasil survei praktik menguras bak mandi seminggu sekali pada seluruh sampel responden di Kelurahan Karangpucung dilakukan oleh 59 KK dari $69 \mathrm{KK}$ yang memiliki bak mandi dengan persentase sebesar $86 \%$.
Hasil survei praktik menguras bak mandi seminggu sekali pada 12 RW adalah sebagai berikut:

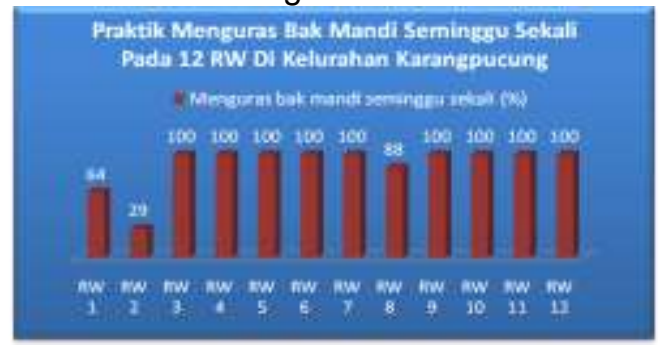

Gambar 4.2

Grafik Praktik Menguras Bak Mandi di 12 RW Kelurahan Karangpucung

Praktik menguras bak mandi seminggu sekali pada setiap RW yaitu di RW 1 sebanyak $7 \mathrm{KK}$ dari $11 \mathrm{KK}$ yang mempunyai bak mandi $(64 \%)$, RW 2 sebanyak 2 KK dari 7 KK yang mempunyai bak mandi (29\%), RW 8 sebanyak $7 \mathrm{KK}$ dari $8 \mathrm{KK}$ yang mempunyai bak mandi (88\%). Semua responden melakukan praktik menguras bak mandi seminggu sekali pada respoden yang mempunyai bak mandi dengan persentase $100 \%$ yaitu di RW 3 sebanyak 5 KK, RW 4 sebanyak $7 \mathrm{KK}$, RW 5 sebanyak 3 KK, RW 6 sebanyak 6 KK, RW 7 sebanyak $7 \mathrm{KK}$, RW 9 sebanyak 4 KK, RW 10 sebanyak 4 KK, RW 11 sebanyak 5 KK, RW 12 sebanyak 2 KK.

2) Menutup tempat penampungan air Praktik menutup tempat penampungan air (tempayan, gentong, drum atau sejenisnya) pada seluruh masyarakat yang disurvei sebanyak $62 \mathrm{KK}$ dari $68 \mathrm{KK}$ yang mempunyai tempat penampungan air dengan persentase 91\%. Praktik menutup tempat penampungan air pada setiap RW dapat dilihat pada grafik berikut:

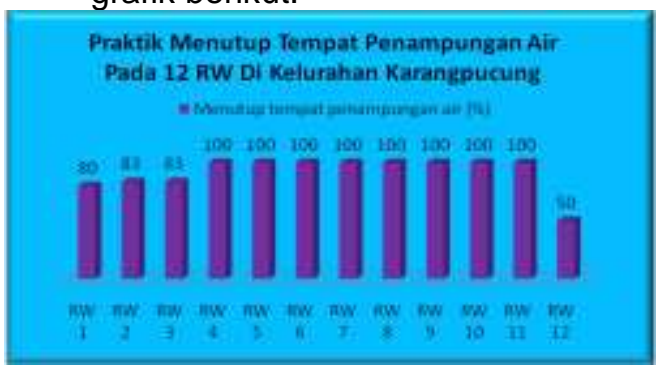

Gambar 4.3

Grafik Praktik Mengubur Tempat

Penampungan Air Pada 12 RW Kelurahan Karangpucung 
Praktik menutup Tempat Penampungan Air (TPA) seperti tempayan, gentong, drum atau sejenisnya dilakukan responden pada setiap RW yang disurvei yaitu RW 1 sebanyak $8 \mathrm{KK}$ dari $10 \mathrm{KK}$ yang memiliki TPA (80\%), RW 2 sebanyak $5 \mathrm{KK}$ dari $6 \mathrm{KK}$ yang memiliki TPA (83\%), RW 3 sebanyak 5 KK dari 6 KK yang memiliki TPA (83\%), RW 12 sebanyak $1 \mathrm{KK}$ dari $2 \mathrm{KK}$ yang memiliki TPA (50\%). Semua responden yang melakukan praktik tersebut dengan presentase $100 \%$ yaitu di RW 4 sebanyak 6 KK, RW 5 sebanyak $5 \mathrm{~K}$, RW 6 sebanyak $3 \mathrm{KK}$, RW 7 sebanyak 7 KK, $R W \quad 8$ sebanyak $11 \mathrm{KK}$, RW 9 sebanyak 3 KK, RW 10 sebanyak 5 KK, RW 11 sebanyak $4 \mathrm{KK}$.

3) Mengubur atau membersihkan pekarangan dari barang bekas

$$
\text { Praktik mengubur }
$$

atau

membersihkan pekarangan dari barang bekas pada seluruh responden yang disurvei di Kelurahan Karangpucung dilakukan oleh $70 \mathrm{KK}$ dari $98 \mathrm{KK}$ yang telah disurvei dengan persentase $71 \%$.Praktik mengubur atau membersihkan pekarangan dari barang bekas pada 12 RW dapat dilihat pada grafik berikut:

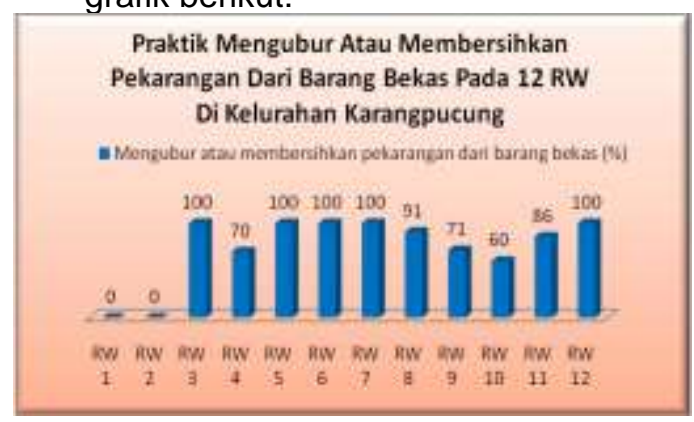

Gambar 4.4

Grafik Praktik Mengubur Atau Membersihkan Pekarangan Dari Barang Bekas Pada 12 RW

Di Kelurahan Karangpucung

Praktik mengubur atau membersihkan pekarangan dari barang bekas di RW 1 dan RW 2 tidak ada yang melaksanakannya $(0 \%)$. Sebagian responden melakukan praktik tersebut yaitu di RW 4 sebanyak 7 KK dari 10 KK yang disurvei (70\%), RW 8 sebanyak $10 \mathrm{KK}$ dari $11 \mathrm{KK}$ yang disurvei (91\%). RW 9 sebanyak 5 KK dari 7 KK yang disurvei (71\%). RW 10 sebanyak $3 \mathrm{KK}$ dari $5 \mathrm{KK}$ yang disurvei $(60 \%)$. RW 11 sebanyak 6 KK dari $7 \mathrm{KK}$ yang disurvei (86\%). Seluruh sampel yang melakukan praktik tersebut dengan presentase $100 \%$ yaitu di RW 3 (7 KK), RW 5 (7 KK), RW 6 (10 KK), RW 7 (11 KK), RW 12 (4 KK).

4) Menutup lubang pada potongan bambu/pohon

Hasil survei mengenai pelaksanaan menutup lubang pada potongan bambu/pohon pada seluruh responden di Kelurahan Karangpucung yaitu sebanyak $16 \mathrm{KK}$ melakukan praktik tersebut dari $30 \mathrm{KK}$ yang mempunyai pohon dirumahnya dengan prosentase $53 \%$. Praktik menutup lubang pada potongan bambu/pohon pada $12 \mathrm{RW}$ dapat dilihat pada tabel berikut:

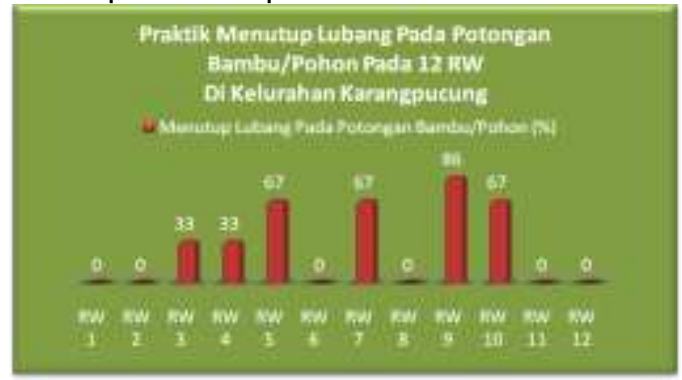

Gambar 4.5

Grafik Praktik Menutup Lubang Pada Potongan Bambu/Pohon

Pada 12 RW Di Kelurahan Karangpucung

Praktik menutup lubang pada potongan bambu/pohon dilakukan oleh responden pada setiap RW yaitu di RW 3 sebanyak $1 \mathrm{KK}$ dari $3 \mathrm{KK}$ yang mempunyai pohon (33\%), RW 4 sebanyak $1 \mathrm{KK}$ dari $3 \mathrm{KK}$ yang mempunyai pohon (33\%), RW 5 sebanyak $2 \mathrm{KK}$ dari $3 \mathrm{KK}$ yang mempunyai pohon (67\%), RW 7 sebanyak $4 \mathrm{KK}$ dari $6 \mathrm{KK}$ yang mempunyai pohon (67\%), RW 9 sebanyak $6 \quad \mathrm{KK}$ dari $7 \mathrm{KK}$ yang mempunyai pohon (86\%), RW 10 sebanyak $2 \mathrm{KK}$ dari $3 \mathrm{KK}$ yang yang mempunyai pohon $(67 \%)$. Responden yang tidak melakukan praktik menutup lubang pada potongan bambu/pohon dengan presentase $0 \%$ yaitu di RW 1 , RW 2, RW 6, RW 8, RW 11 dan RW 12.

5) Mengganti air vas bunga seminggu sekali

Praktik mengganti air pada vas bunga seminggu sekali di Kelurahan Karangpucung sebanyak $10 \quad \mathrm{KK}$ 
melakukannya dari $10 \quad \mathrm{KK}$ yang mempunyai vas bunga dengan persentase $100 \%$. Praktik mengganti air pada vas bunga seminggu sekali pada $12 \mathrm{RW}$ dapat dilihat pada grafik berikut:

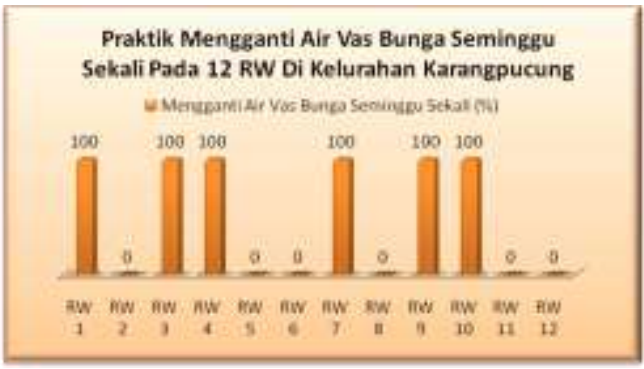

Gambar 4.6

Grafik Praktik Mengganti Air Pada Vas Bunga Seminggu Sekali Pada 12 RW

Di Kelurahan Karangpucung

Praktik mengganti air pada vas bunga seminggu sekali dilakukan oleh sampel di RW 1 sebanyak $1 \mathrm{KK}$ dari 1 KK yang mempunyai vas bunga (100\%), RW 3 sebanyak $3 \mathrm{KK}$ dari $3 \mathrm{KK}$ yang mempunyai vas bunga (100\%), RW 4 sebanyak 2 KK dari 2 KK yang mempunyai vas bunga (100\%), RW 7 sebanyak $1 \mathrm{KK}$ dari $1 \mathrm{KK}$ yang mempunyai vas bunga (100\%), RW 9 sebanyak $1 \mathrm{KK}$ dari $1 \mathrm{KK}$ yang mempunyai vas bunga (100\%), RW 10 sebanyak 2 KK dari 2 KK yang mempunyai vas bunga (100\%). RW yang tidak melakukan praktik tersebut karena tidak mempunyai vas bunga (0\%) adalah RW 2, RW 5, RW 6, RW 8, RW 11 dan RW 12.

6) Membersihkan tempat minum burung seminggu sekali

Praktik membersihkan tempat minum burung seminggu sekali dilakukan oleh $27 \mathrm{KK}$ dari $27 \mathrm{KK}$ yang memelihara burung dengan persentase $100 \%$. Praktik membersihkan tempat minum burung seminggu sekali di 12 RW dapat dilihat pada grafik berikut ini:
Praktik Membersihkan Tempat Minum Burung Seminggu Sekali Pada 12 RW Di Kelurahan Karangpucung

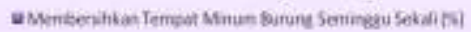

$\begin{array}{llllllllll}100 & 100 & 100 & 100 & 100 & 100 & 100 & 100 \quad 100 & 100\end{array}$ กากด 1010

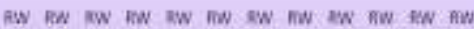

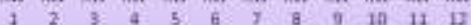

Gambar 4.7

Grafik Praktik Membersihkan Tempat Minum Burung Seminggu Sekali Pada 12 RW Di Kelurahan Karangpucung

Praktik membersihkan tempat
minum burung seminggu sekali dilakukan semua responden yang memelihara burung dengan presentase $100 \%$ yaitu di RW 1 sebanyak 1 KK dari $1 \mathrm{KK}$ yang mempunyai burung, RW 2 sebanyak $2 \mathrm{KK}$ dari $2 \mathrm{KK}$ yang mempunyai burung, RW 3 sebanyak 1 $\mathrm{KK}$ dari $1 \mathrm{KK}$ yang mempunyai burung, RW 4 sebanyak 4 KK dari 4 KK yang mempunyai burung, RW 5 sebanyak 3 $\mathrm{KK}$ dari $3 \mathrm{KK}$ yang mempunyai burung, RW 6 sebanyak $4 \mathrm{KK}$ dari $4 \mathrm{KK}$ yang mempunyai burung, RW 7 sebanyak 4 KK dari $4 \mathrm{KK}$ yang mempunyai burung, RW 8 sebanyak 4 KK dari 4 KK yang mempunyai burung, RW 9 sebanyak 1 $\mathrm{KK}$ dari $1 \mathrm{KK}$ yang mempunyai burung, RW 10 sebanyak $3 \mathrm{KK}$ dari $3 \mathrm{KK}$ yang mempunyai burung. RW 11 dan RW 12 tidak melakukan praktik tersebut karena tidak ada yang memelihara burung.

7) Menggunakan obat nyamuk

Praktik menggunakan obat nyamuk pada seluruh masyarakat yang disurvei, hasilnya yaitu $65 \mathrm{KK}$ menggunakannya dari total $98 \mathrm{KK}$ yang di survei dengan persentase $66 \%$. Praktik menggunakan obat nyamuk pada $12 \mathrm{RW}$ dapat dilihat pada grafik berikut:

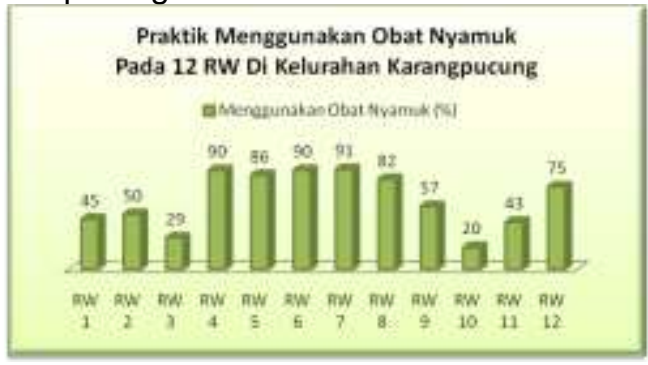

Gambar 4.8

Grafik Praktik Menggunakan Obat Nyamuk Pada 12 RW Di Kelurahan Karangpucung 
Penggunaan obat nyamuk di RW 1 sebanyak $5 \mathrm{KK}$ dari $11 \mathrm{KK}$ yang disurvei (45\%), RW 2 sebanyak 4 KK dari 8 KK yang disurvei (50\%), RW 3 sebanyak $2 \mathrm{KK}$ dari $7 \mathrm{KK}$ yang disurvei (29\%), RW 4 sebanyak 9 KK dari $10 \mathrm{KK}$ yang disurvei (90\%), RW 5 sebanyak 6 KK dari 7 KK yang disurvei (86\%), RW 6 sebanyak 9 KK dari $10 \mathrm{KK}$ yang disurvei (90\%), RW 7 sebanyak $10 \mathrm{KK}$ dari $11 \mathrm{KK}$ yang disurvei (91\%), RW 8 sebanyak $9 \mathrm{KK}$ dari $11 \mathrm{KK}$ yang disurvei (82\%), RW 9 sebanyak 4 KK dari 7 KK yang disurvei (57\%), RW 10 sebanyak $1 \mathrm{KK}$ dari $5 \mathrm{KK}$ yang disurvei (20\%), RW 11 sebanyak 3 KK dari 7 KK yang disurvei (43\%), RW 12 sebanyak 3 KK dari 4 KK yang disurvei (75\%).

8) Tidur menggunakan kelambu

Tidur menggunakan kelambu pada responden di Kelurahan Karangpucung sebanyak 4 KK melakukannya dari 98 $\mathrm{KK}$ yang disurvei dengan persentase 4\%. Praktik tidur menggunakan kelambu di 12 RW dapat dilihat pada grafik berikut:

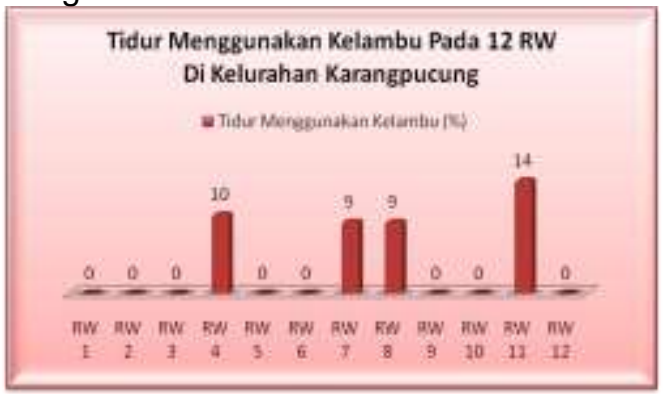

Gambar 4.9

Grafik Tidur Menggunakan Kelambu Pada 12 RW Di Kelurahan Karangpucung

Penggunaan kelambu dilakukan di RW 4 sebanyak $1 \mathrm{KK}$ dari $10 \mathrm{KK}$ yang disurvei (10\%), RW 7 sebanyak $1 \mathrm{KK}$ dari $11 \mathrm{KK}$ yang disurvei (9\%), RW 8 sebanyak $1 \mathrm{KK}$ dari $11 \mathrm{KK}$ yang disurvei (9\%), RW 11 sebanyak $1 \mathrm{KK}$ dari 7 KK yang disurvei (14\%). RW yang tidak menggunakan kelambu saat tidur dengan presentase $0 \%$ adalah di RW 1, RW 2, RW 3, RW 5, RW 6, RW 9, RW 10 dan RW 12.

9) Menggunakan kawat kasa pada lubang ventilasi

Praktik menggunakan kawat kasa pada lubang ventilasi di Kelurahan Karangpucung sebanyak 12 KK melakukannya dari $98 \mathrm{KK}$ yang telah disurvei dengan persentase $12 \%$.
Penggunaan kawat kasa pada lubang ventilasi di $12 \mathrm{RW}$ dapat dilihat pada grafik berikut:

Mengsunakan Kawat Kasa Pada Lubang Ventilasí Pada 12 RW Di Kelurahan Karangpucung

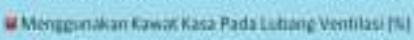

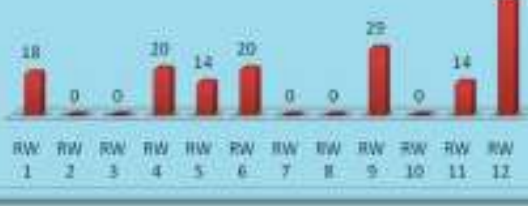

Gambar 4.10

Grafik Penggunaan Kawat Kasa Pada Lubang Ventilasi Pada 12 RW Di Kelurahan Karangpucung

Penggunaan kawat kasa pada lubang ventilasi dilakukan oleh responden di masing-masing RW yaitu RW 1 sebanyak 2 KK dari $11 \mathrm{KK}$ yang disurvei (11\%), RW 4 sebanyak 2 KK dari $10 \mathrm{KK}$ yang disurvei $(20 \%)$, RW 5 sebanyak $1 \mathrm{KK}$ dari $7 \mathrm{KK}$ yang disurvei (14\%), RW 6 sebanyak 2 KK dari $10 \mathrm{KK}$ yang disurvei (20\%), RW 9 sebanyak 2 KK dari 7 KK yang disurvei $(29 \%)$, RW 11 sebanyak 1 KK dari 7 KK yang disurvei (14\%), RW 12 sebanyak 2 KK dari 4 KK yang disurvei (50\%). RW yang tidak menggunaan kawat kasa pada lubang ventilasi dengan persentase $0 \%$ yaitu di RW 2, RW 3, RW 7, RW 8 dan RW 10.

10) Menaburi abate 3 bulan sekali pada tempat penampungan air yang jarang dikuras

Praktik menaburi abate 3 bulan sekali pada tempat penampungan air yang jarang dikuras di Kelurahan Karangpucung sebanyak $17 \quad \mathrm{KK}$ melakukannya dari $98 \quad \mathrm{KK}$ yang mempunyai tempat penampungan air (bak mandi, tempayan, tandon air dan sebagainya) dengan persentase $17 \%$. Praktik menaburi abate 3 bulan sekali di 12 RW dapat dilihat pada grafik berikut ini: 


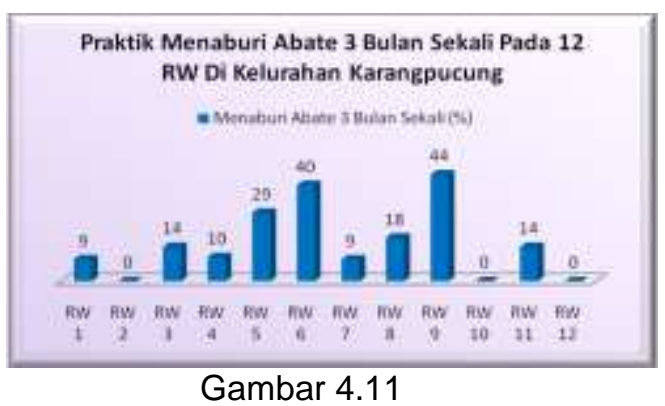

Grafik Praktik Menaburi Abate 3 Bulan Sekali Pada 12 RW Di Kelurahan Karangpucung

Penaburan abate 3 bulan sekali pada tempat penampungan air yang jarang dikuras dilakukan oleh RW 1 sebanyak $1 \mathrm{KK}$ dari $11 \mathrm{KK}$ yang disurvei (9\%), RW 3 sebanyak $1 \mathrm{KK}$ dari $7 \mathrm{KK}$ yang disurvei (14\%), RW 4 sebanyak 1 KK dari $10 \mathrm{KK}$ yang disurvei (10\%), RW 5 sebanyak 2 KK dari 7 KK yang disurvei (29\%), RW 6 sebanyak $4 \mathrm{KK}$ dari $10 \mathrm{KK}$ yang disurvei (40\%), RW 7 sebanyak $1 \mathrm{KK}$ dari $11 \mathrm{KK}$ yang disurvei (9\%), RW 8 sebanyak 2 KK dari 11 KK yang disurvei (18\%), RW 9 sebanyak $4 \mathrm{KK}$ dari 9 KK yang disurvei (44\%), RW 11 sebanyak $1 \mathrm{KK}$ dari $7 \mathrm{KK}$ yang disurvei $(14 \%)$. RW yang tidak melakukan penaburan abate 3 bulan sekali dengan persentase $0 \%$ yaitu di RW 2, RW 10 dan RW 12.

11) Memelihara ikan pemakan jentik

Praktik memelihara ikan pemakan jentik di Kelurahan Karangpucung sebanyak $6 \quad \mathrm{KK}$ dari $98 \quad \mathrm{KK}$ yang disurvei dengan persentase 6\%. Praktik pemeliharaan ikan pemakan jentik pada 12 RW di Kelurahan Karangpucung adalah berikut:

Praktik Memelihara Ikan Pemakan Jentik Pada

12 RW Di Kelurahan Karangpucung

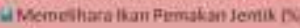

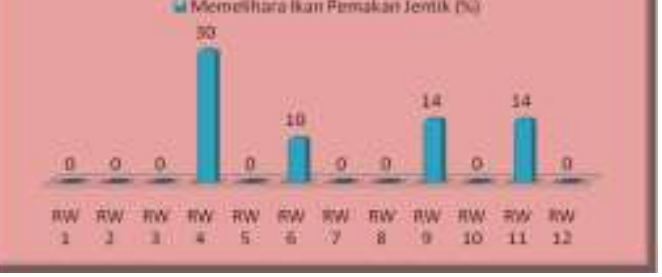

Gambar 4.12

Grafik Praktik Pemeliharaan Ikan Pemakan Jentik Pada 12 RW

Di Kelurahan Karangpucung

Pemeliharaan ikan pemakan jentik dilakukan pada setiap RW yaitu di RW 4 sebanyak $3 \mathrm{KK}$ dari $10 \mathrm{KK}$ yang disurvei (30\%), RW 6 sebanyak $1 \mathrm{KK}$ dari $10 \mathrm{KK}$ yang disurvei (10\%), RW 9 sebanyak $1 \mathrm{KK}$ dari $7 \mathrm{KK}$ yang disurvei (14\%) dan RW 11 sebanyak $1 \mathrm{KK}$ dari 7 KK yang disurvei (14\%). RW yang tidak memelihara ikan pemakan jentik dengan presentase $0 \%$ yaitu RW 1 , RW 2, RW 3, RW 5, RW 7, RW 8, RW 10, dan RW 12.

12) Tidak menggantungkan pakaian di dalam rumah

Praktik tidak menggantungkan pakaian di dalam rumah sebanyak 29 KK melakukannya dari $98 \mathrm{KK}$ yang disurvei di Kelurahan Karangpucung dengan persentase $30 \%$. Praktik tidak menggantungkan pakaian di dalam rumah pada $12 \mathrm{RW}$ adalah sebagai berikut:

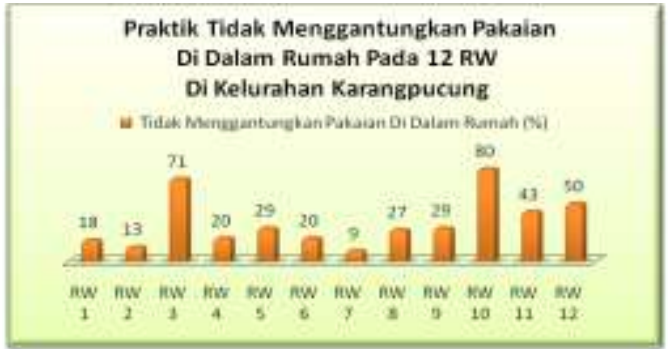

Gambar 4.13

Grafik Praktik Tidak Menggantungkan

Pakaian Di Dalam Rumah Pada 12 RW

Di Kelurahan Karangpucung

Praktik tidak mengggantungkan pakaian di dalam rumah dilakukan pada responden di masing-masing RW yaitu di RW 1 sebanyak 2 KK dari $11 \mathrm{KK}$ yang di survei (18\%), RW 2 sebanyak 1 KK dari $8 \mathrm{KK}$ yang di survei (13\%), RW 3 sebanyak $5 \mathrm{KK}$ dari $7 \mathrm{KK}$ yang disurvei (71\%), RW 4 sebanyak 2 KK dari 10 KK yang di survei (20\%), RW 5 sebanyak $2 \mathrm{KK}$ dari $7 \mathrm{KK}$ yang disurvei (29\%), RW 6 sebanyak 2 KK dari 10 KK yang disurvei (20\%), RW 7 sebanyak 1 KK dari $11 \mathrm{KK}$ yang disurvei $(9 \%)$, RW 8 sebanyak $3 \mathrm{KK}$ dari $11 \mathrm{KK}$ yang disurvei (27\%), RW 9 sebanyak 2 KK dari 7 KK yang disurvei (29\%), RW 10 sebanyak $4 \mathrm{KK}$ dari $5 \mathrm{KK}$ yang disurvei (80\%), RW 11 sebanyak $3 \mathrm{KK}$ dari $7 \mathrm{KK}$ yang disurvei (43\%), RW 12 sebanyak 2 KK dari $4 \mathrm{KK}$ yang disurvei (50\%).

13) Memperbaiki talang air yang rusak

Praktik memperbaiki talang air yang rusak pada seluruh responden di Kelurahan Karangpucung dilakukan oleh $82 \mathrm{KK}$ dari $98 \mathrm{KK}$ yang disurvei 
dengan persentase 84\%. Praktik memperbaiki talang air yang rusak di 12 RW adalah sebagai berikut:

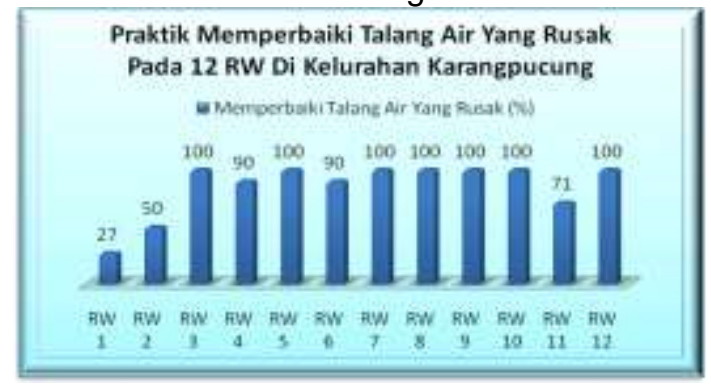

Gambar 4.14

Grafik Praktik Memperbaiki Talang Air Yang Rusak Pada 12 RW

Di Kelurahan Karangpucung

Praktik memperbaiki talang air yang rusak pada responden di setiap RW yaitu dilakukan di RW 1 sebanyak $3 \mathrm{KK}$ dari $11 \mathrm{KK}$ yang disurvei $(27 \%)$, RW 2 sebanyak 4 KK dari 8 KK yang disurvei $(50 \%)$, RW 4 sebanyak 9 KK dari $10 \mathrm{KK}$ yang disurvei (90\%), RW 6 sebanyak $9 \mathrm{KK}$ dari $10 \mathrm{KK}$ yang disurvei (90\%), RW 11 sebanyak $5 \mathrm{KK}$ dari 7 KK yang disurvei (71\%). Praktik memperbaiki talang air yang rusak dilakukan oleh seluruh responden yang disurvei dengan presentase $100 \%$ yaitu di RW 3 sebanyak 7 KK, RW 5 sebanyak $7 \mathrm{KK}$, RW 7 sebanyak $11 \mathrm{KK}$, RW 8 sebanyak $11 \mathrm{KK}$, RW 9 sebanyak $7 \mathrm{KK}$, RW 10 sebanyak $5 \mathrm{KK}$ dan RW 12 sebanyak $4 \mathrm{KK}$.

Berdasarkan hasil survei pelaksanaan PSN DBD terdapat urutan masalah yang nilainya masih rendah yaitu sebagai berikut:
a. Tidur menggunakan kelambu (4\%).
b. Memelihara ikan pemakan jentik (6\%)
c. Penggunaan kawat kasa pada lubang ventilasi $(12 \%)$
d. Penaburan abate (17\%)

Hasil penilaian pada seluruh item kuesioner mengenai pelaksanaan PSN DBD di 12 RW Kelurahan Karangpucung adalah berikut:

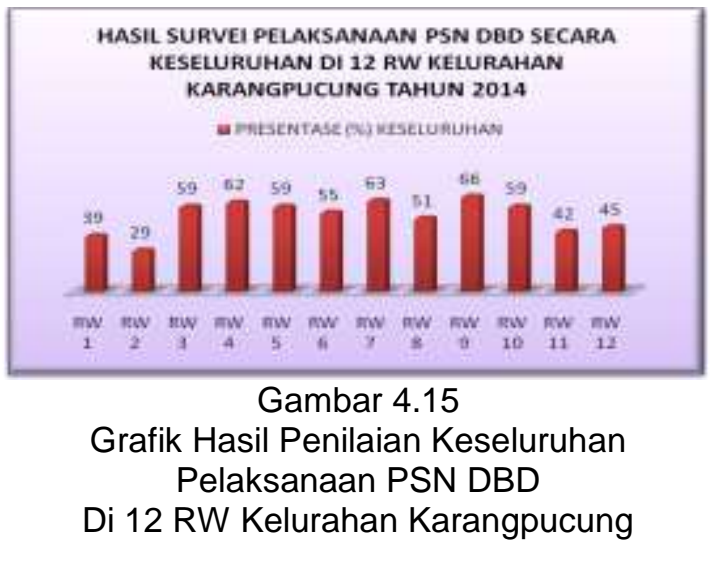

Berdasarkan grafik tersebut dapat diketahui praktik PSN DBD yang paling rendah di RW 2 dan RW 1 sedangkan praktik PSN DBD yang paling tinggi di RW 7 dan RW 9.

2. Perhitungan Angka Bebas Jentik (ABJ), House Index $(\mathrm{HI})$, Container Index $(\mathrm{Cl})$, dan Breteu Index (BI) di Kelurahan Karangpucung.

Survei jentik di Kelurahan Karangpucung dilakukan dengan jumlah rumah yang di survei sebanyak 98 rumah. Survei jentik yang dilakukan dengan menggunakan metode visual, yang merupakan survei lanjutan untuk memonitor indek-indek jentik atau menilai hasil PSN. Jentik nyamuk ditemukan di berbagai macam penampungan air yaitu 5 dispenser positif jentik, 6 bak mandi positif jentik, 2 drum positif jentik, 1 pecahan gelas di halaman rumah positif jentik, 2 tempayan positif jentik, 1 batok kelapa di halaman rumah positif jentik, 6 pot bunga positif jentik, dan 1 di tempat bekas makanan. Kepadatan jentik dapat diketahui dengan melakukan perhitungan Angka Bebas Jentik (ABJ), Container Index $(\mathrm{Cl})$, House Index $(\mathrm{HI})$ dan Breteu Index (BI). Hasil perhitungan tersebut dapat dilihat pada tabel berikut: 
Tabel 4. 5 : Hasil Pemerikasaan Jentik di Kelurahan Karangpucung Tahun 2014

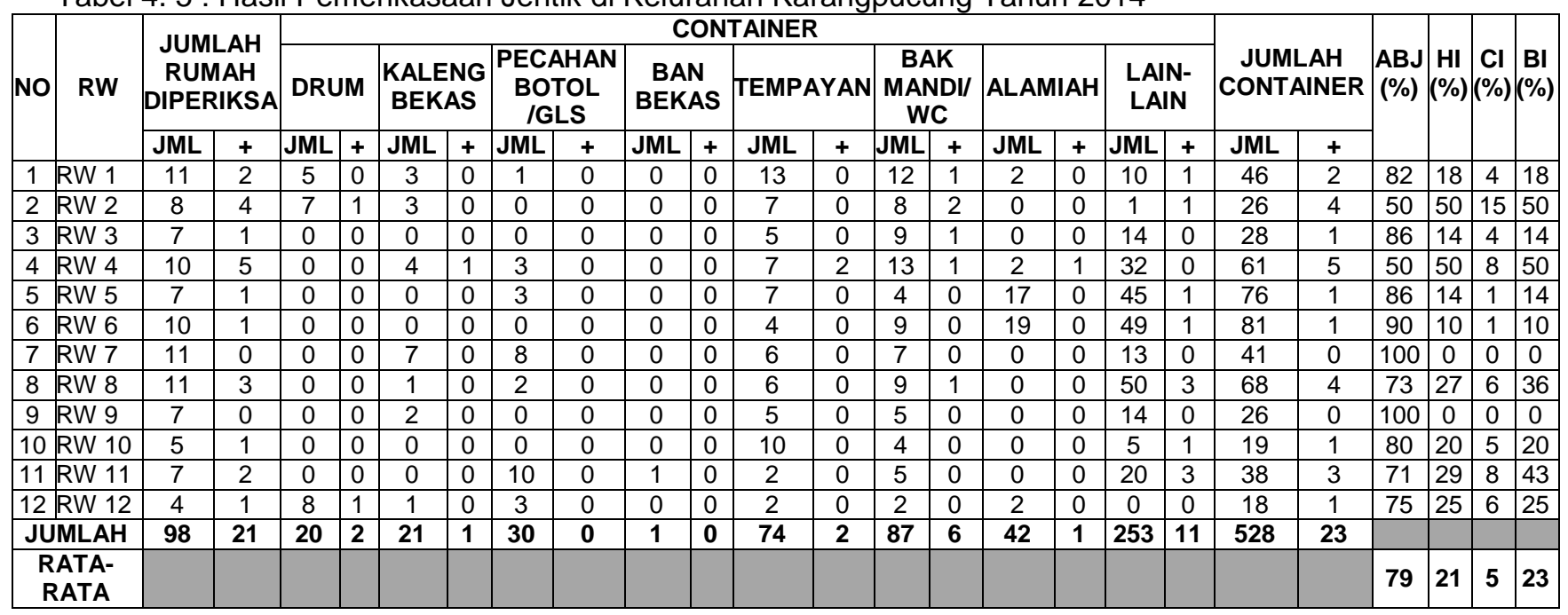

Berdasarkan tabel tersebut dapat diketahui bahwa dari 98 sampel rumah yang diperiksa di Kelurahan Karangpucung, 21 rumah positif jentik nyamuk. Container yang diperiksa seluruhnya berjumlah 528 dan 23 container positif jentik nyamuk. Container yang positif jentik yaitu di 6 bak mandi, 4 dispenser, 2 drum, 1 pecahan gelas, 2 tempayan, TPA alami yaitu 1 batok, dan di lain-lain yaitu 6 pot bunga dan 1 tempat bekas makanan. Berdasarkan data tersebut dapat dilakukan perhitungan sebagai berikut:

a. Angka Bebas Jentik (ABJ)

$$
\begin{aligned}
\text { ABJ }(\%)= & \frac{\text { Jumlah rumah tidak ditemulanjentik Ades swp }}{\text { Jumlah rumahyang diperiks }} \text { N1000\% } \\
& =\frac{77}{98} \times 100 \% \\
& =79 \%
\end{aligned}
$$

Angka Bebas Jentik (ABJ) sebesar 79\%

b. House Index $(\mathrm{HI})$

$$
\begin{aligned}
\mathrm{HI}(\%) & =\frac{\text { Jumlah rumah positif jentik Aedes spp }}{\text { Jumlah rumah yang diperiksa }} \times 100 \% \\
& =\frac{21}{98} \times 100 \% \\
& =21 \%
\end{aligned}
$$

House Index $(\mathrm{HI})$ sebesar $21 \%$

c. Container Index (Cl)

$$
\begin{aligned}
\mathrm{Cl}(\%) & =\frac{\text { Jumlah container ditemukan jentik Aedes spp }}{\text { Jumlah containeryang diperiksa }} \mathrm{x} 100 \% \\
& =\frac{23}{528} \times 100 \% \\
& =5 \%
\end{aligned}
$$

Container Index $(\mathrm{Cl})$ sebesar $5 \%$ d. Breteu Index (BI)

$\mathrm{BI}(\%)=$ Jumlah container positif jentik Aedes spp

$$
\begin{aligned}
& \text { Jumlah rumahyang diperiksa } \\
= & \frac{23}{98} \times 100 \% \\
= & 23 \%
\end{aligned}
$$

Breteu Index (BI) sebesar 23\%.

Hasil survei jentik disetiap RW yang ada di Kelurahan Karangpucung dengan jumlah 12 RW adalah sebagai berikut:

a. Angka Bebas Jentik (ABJ)

Hasil perhitungan Angka Bebas Jentik (ABJ) RW 1 sebesar $82 \%$, RW 2 sebesar $50 \%$, RW 3 sebesar $86 \%$, RW 4 sebesar $50 \%$, RW 5 sebesar $86 \%$, RW 6 sebesar $90 \%$, RW 7 sebesar $100 \%$, RW 10 sebesar $80 \%$, RW 11 sebesar $71 \%$ dan RW 12 sebesar $75 \%$.

b. House Index (HI)

Hasil perhitungan House Index (HI) RW 1 sebesar $18 \%$, RW 2 sebesar $50 \%$, RW 3 sebesar 14\%, RW 4 sebesar $50 \%$, RW 5 sebesar $14 \%$, RW 6 sebesar $10 \%$, RW 7 sebesar $0 \%$, RW 8 sebesar $27 \%$, RW 9 sebesar 0\%, RW 10 sebesar $20 \%$, RW 11 sebesar 29\%, RW 12 sebesar $25 \%$.

c. Container Index (CI)

Hasil perhitungan Container Index (CI) RW 1 sebesar 4\%, RW 2 sebesar $15 \%$, RW 3 sebesar 4\%, RW 4 sebesar $8 \%$, RW 5 sebesar $1 \%$, RW 6 sebesar $1 \%$, RW 7 sebesar $0 \%$, RW 8 sebesar $6 \%$, RW 9 sebesar 0\%, RW 10 sebesar $5 \%$, RW 11 sebesar 8\%, RW 12 sebesar $6 \%$ 


\section{d. Breteu Index (BI)}

Hasil perhitungan Breteu Index (BI) RW 1 sebesar $18 \%$, RW 2 sebesar $50 \%$, RW 3 sebesar $14 \%$, RW 4 sebesar $50 \%$, RW 5 sebesar $14 \%$, RW 6 sebesar $10 \%$, RW 7 sebesar $0 \%$, RW 8 sebesar $36 \%$, RW 9 sebesar $0 \%$, RW 10 sebesar $20 \%$, RW 11 sebesar 43\%, RW 12 sebesar $25 \%$.

3. Membandingkan Angka Bebas Jentik (ABJ), House Index (HI), Container Index (Cl) dan Breteu Index (BI) dengan standar atau peraturan yang berlaku.

Hasil perhitungan Angka Bebas Jentik (ABJ) di Kelurahan Karangpucung dengan sampel 98 rumah secara keseluruhan didapatkan hasil $79 \%$, apabila dibandingan dengan standar dari Depkes RI tidak memenuhi syarat karena ABJ belum mencapai 95\%. Hasil perhitungan House Index (HI) di Kelurahan Karangpucung sebesar $21 \%$, $\mathrm{HI}$ tersebut tidak memenuhi syarat bila dibandingkan dengan peraturan WHO karena $\mathrm{HI} \geq 10 \%$. Hasil perhitungan Container Index (CI) di Kelurahan Karangpucung sebesar 5\%, apabila dibandingkan dengan standar peraturan WHO tidak memenuhi syarat karena $\mathrm{Cl} \geq$ $5 \%$. Hasil perhitungan Breteu Index (BI) sebesar $23 \%$, apabila dibandingan dengan standar peraturan WHO memenuhi Syarat karena $\mathrm{Bl}<50 \%$.

Hasil perhitungan $\mathrm{ABJ}, \mathrm{HI}, \mathrm{Cl}$ dan $\mathrm{BI}$ pada 12 RW di Kelurahan Karangpucung dibandingakan standar dapat dijabarkan seperti berikut:

\section{a. Angka Bebas Jentik (ABJ)}

Angka Bebas Jentik (ABJ) pada 12 RW di Kelurahan Karangpucung dapat dilihat pada grafik berikut:

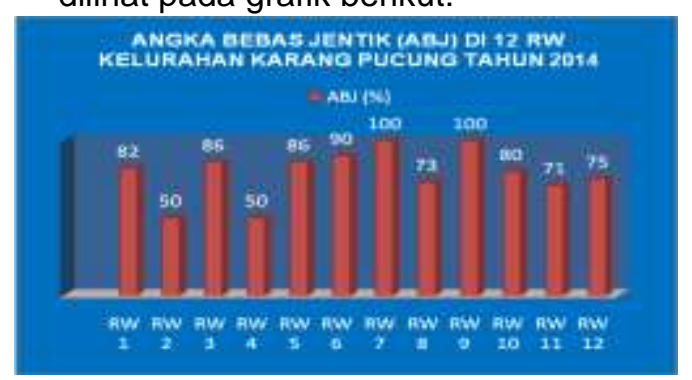

Gambar 4.16

Grafik Angka Bebas Jentik (ABJ)

DI 12 RW Kelurahan Karangpucung

Berdasarkan grafik tersebut dapat diketahui Angka Bebas Jentik (ABJ) di RW 7 dan RW 9 memenuhi syarat karena $A B J \geq 95 \%$. Angka Bebas Jentik (ABJ) di RW 1, RW 2, RW 3, RW 4,
RW 5, RW 6, RW 8, RW 10, RW 11, RW 12 tidak memenuhi syarat jika dibandingkan dengan standar dari Depkes RI belum mencapai ABJ 95\%. RW yang memiliki $A B J$ paling rendah yaitu RW 2 dan RW 4 (50\%), sedangkan jumlah kasus DBD tertinggi yaitu di RW 4 (5 kasus) dan untuk RW 2 jumlah kasus DBD sebanyak 1 kasus. $A B J$ yang paling tinggi di RW 7 dan RW 9, jumlah kasus DBD di RW 7 (1 kasus), sedangkan di RW 9 tidak ada kasus DBD pada tahun 2013.

b. House Index $(\mathrm{HI})$

House Index $(\mathrm{HI})$ pada $12 \mathrm{RW}$ di Kelurahan Karangpucung dapat dilihat pada grafik berikut:

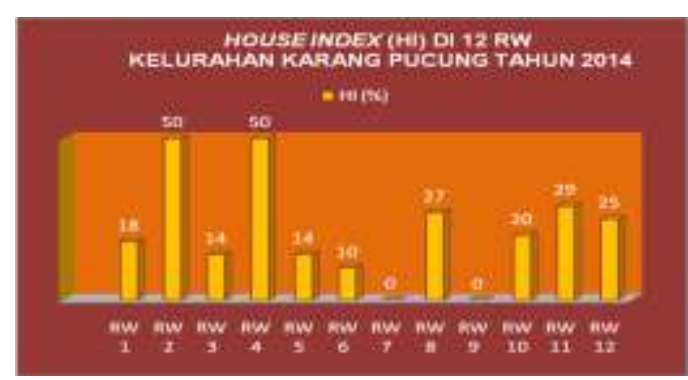

Gambar 4.17

Grafik House Index (HI) Di 12 RW

Kelurahan Karangpucung

Berdasarkan grafik tersebut dapat diketahui bahwa House Index (HI) RW 7 dan RW 9 memenuhi standar peraturan WHO karena $\mathrm{HI}<10 \%$, House Index (HI) di RW 1, RW 2, RW 3, RW 4, RW 5, RW 6, RW 8, RW 10, RW 11 dan RW 12 tidak memenuhi syarat karena $\mathrm{HI} \geq 10 \%$. $\mathrm{HI}$ yang paling tinggi berada di RW 2 dan RW 4 (50\%). Jumlah kasus DBD di RW 4 (5 kasus) dan RW 2 (1 kasus).

c. Container Index (Cl)

Container Index $(\mathrm{Cl})$ pada $12 \mathrm{RW}$ di Kelurahan Karangpucung dapat dilihat pada grafik berikut:

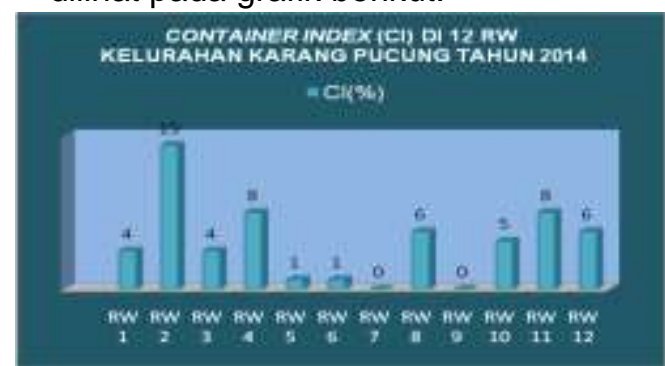

Grafik Container Index $(\mathrm{Cl})$ pada 12 RW Kelurahan Karangpucung 
Berdasarkan grafik tersebut diketahui Container Index (Cl) di RW 1, RW 3, RW 5, RW 6, RW 7, RW 9 memenuhi syarat standar WHO karena $\mathrm{Cl}<5 \%$. Container Index (Cl) di RW 2, RW 4, RW 8, RW 10, RW 11, RW 12 tidak memenuhi syarat karena $\mathrm{Cl} \geq 5 \%$. $\mathrm{Cl}$ yang paling tinggi berada di RW 2 (15\%), RW 4 (8\%) dan RW 11 (8\%). Jumlah kasus DBD di RW 2 (1 kasus), RW 4 (5 kasus), RW 11 ( 0 kasus).

d. Breteu Index (BI)

Breteu Index (BI) pada 12 RW di Kelurahan Karangpucung dapat dilihat pada grafik berikut:

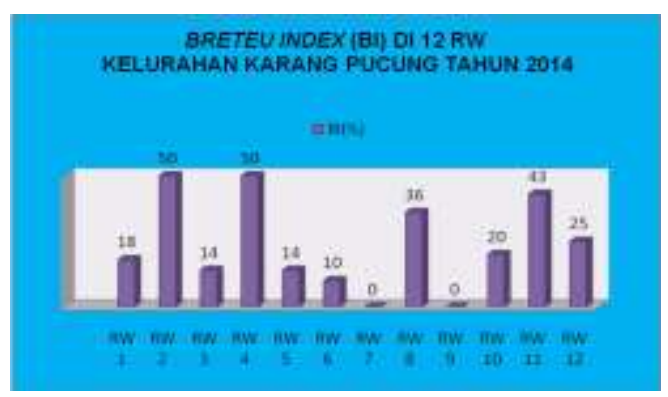

Gambar 4.19

Grafik Breteu Index (BI) pada 12 RW Kelurahan Karangpucung

Berdasarkan grafik tersebut dapat diketahui Breteu Index (BI) di RW 1, RW 3, RW 5, RW 6, RW 7, RW 8, RW 9, RW 10, RW 11, RW 12 memenuhi syarat karena $\mathrm{BI}<50 \%$. Breteu Index (BI) di RW 2 dan RW 4 tidak memenuhi syarat karena $\mathrm{BI}>50 \%$. Jumlah kasus DBD di RW 2 (1 kasus) dan RW 4 (5 kasus).

\section{PEMBAHASAN}

A. Gambaran Umum Kelurahan

Karangpucung Kecamatan Purwokerto Selatan Kabupaten Banyumas

1. Keadaan Geografis

Kelurahan Karangpucung merupakan salah satu dari 7 kelurahan yang ada di Kecamatan Purwokerto Selatan dengan luas wilayah 156,00 Ha. Wilayah Kelurahan Karangpucung terdiri dari tanah persawahan seluas pekarangan/bangunan, kolam, hutan rakyat dan lain-lain. Secara kewilayahan Kelurahan Karangpucung terbagi menjadi 12 RW dan 56 RT dengan batas wilayahnya yaitu sebelah timur berbatasan dengan kelurahan Purwokerto Kulon, sebelah barat berbatasan dengan Kelurahan Tanjung, sebelah utara berbatasan dengan Kelurahan Kranji, sebelah Selatan berbatasan dengan Kelurahan Karang Klesem.

2. Keadaan Demografi

a. Jumlah Penduduk Menurut Jenis

Kelamin

Jumlah penduduk keseluruhan di

Kelurahan Karangpucung sebanyak 13.318 jiwa dengan jumlah penduduk laki-laki lebih banyak dari jumlah penduduk perempuan yaitu 6.787 jiwa sedangkan jumlah penduduk perempuan sebanyak 6.531 jiwa.

b. Jumlah Penduduk Menurut Kelompok Umur

Jumlah terbesar penduduk menurut kelompok umur adalah pada rentang umur 30-34 tahun dengan jumlah 1.364 orang dan jumlah penduduk terkecil pada rentang umur 90-94 tahun dengan jumlah 11 orang.

c. Jumlah Penduduk Menurut Pendidikan Jumlah penduduk terbesar di Kelurahan Karangpucung adalah pendidikan SMA/Sederajat dengan jumlah 3.590 orang dan jumlah terkecil pada pendidikan Strata III (S3) dengan jumlah 5 orang.

d. Mata Pencaharian Penduduk Mata pencaharian penduduk yang terbesar di Kelurahan Karangpucung adalah tidak bekerja dengan jumlah 2.952 orang dan mata pencaharian yang jumlahnya terkecil adalah wartawan, ustad, tukang cukur, tabib, seniman, physikiater, promotor acara, pengacara, penata busana, pelaut, pastur, notaris, buruh tani, buruh ternak dengan jumlah masing-masing 1 orang.

3. Keadaan Topografi

Keadaan topografi Kelurahan

Karangpucung terletak pada ketinggian 74 $\mathrm{m}$ dari permukaan laut. Curah hujan pada wilayah Kelurahan Karangpucung 99 $\mathrm{mm} /$ tahun dengan suhu rata-rata $26,3 \circ \mathrm{C}$. Ketinggian tempat akan berpengaruh terhadap penyebaran nyamuk. Curah hujan akan mempengaruhi kepadatan nyamuk karena dapat menambah jumlah tempat perkembangbiakan nyamuk di luar rumah. Suhu rata-rata $26,3 \subseteq \mathrm{C}$ adalah suhu rata-rata optimum untuk perkembangan nyamuk karena menurut DIT.JEN.PP \& PL (2007a, h.8) suhu optimum perkembangan nyamuk adalah $25^{\circ}-27^{\circ} \mathrm{C}$. Suhu tersebut dapat 
mempengaruhi kepadatan nyamuk di Kelurahan Karangpucung.

\section{B. Data Khusus}

1. Pelaksanaan Pemberantasan Sarang Nyamuk (PSN) Demam Berdarah Dengue (DBD)

Kelurahan Karangpucung telah melakukan kegiatan PSN DBD, terdapat kegiatan bersih-bersih lingkungan dengan kerja bakti warga dilakukan setiap hari Jum'at dan kegiatan survei jentik nyamuk yang di koordinir oleh kader yang ada setiap RW dilakukan setiap hari Minggu. Kader PSN DBD tersebut telah diberi pelatihan oleh Dinas Kesehatan Kabupaten Banyumas sehingga dapat memudahkan pelaksanaan tugasnya. Penyululuhan mengenai DBD dan PSN DBD juga telah dilakukan pada pertemuan PKK atau dawis di setiap RW, hal tersebut dapat memberikan pemahaman kepada masyarakat mengenai DBD sehingga dapat mengerti dalam melaksanakan PSN DBD dirumahnya.

Kader/jumantik yang ada tidak semuanya aktif menjadi kendala pelaksanaan PSN DBD, jika semua kader aktif dengan jumlah 149 kader yang tersebar di masing-masing RW pelaksanaan PSN DBD akan lebih dapat membantu mengurangi kajadian DBD di Kelurahan Karangpucung. Ketersediaan sarana/peralatan salah satu kendala dalam pelaksanaan PSN DBD karena jumlahnya terbatas. Kendala dalam melakukan PSN di Kelurahan Karangpucung adalah kurangnya kesadaran dari masyarakat untuk melakukan PSN, masyarakat yang menjadi kader malas membuat laporan bulanan. Hasil Kegiatan PSN DBD akan efektif menurunkan angka kesakitan DBD jika semua aktif bergerak melaksanakannya yaitu dari kader dan masyarakat.

Pelaksanaan PSN DBD di Kelurahan Karangpucung berdasarkan hasil survei terhadap $98 \mathrm{KK}$ yang tersebar di $12 \mathrm{RW}$ dengan menggunakan instrumen kuesioner adalah sebagai berikut:

\section{a. Pelaksanaan PSN DBD}

Pelaksanaan yang telah dilakukan oleh responden yang disurvei di Kelurahan Karangpucung sebanyak 95 KK dari 98 KK yang disurvei dengan persentase $97 \%$, hal itu menunjukkan telah dilakukan PSN DBD di Kelurahan Karangpucung. KK yang belum melakukan PSN DBD sebanyak $3 \mathrm{KK}$ dengan presentase $3 \%$.

Hasil survei Pelaksanaan

Pemberantasan Sarang Nyamuk (PSN)

Demam Berdarah Dengue (DBD) pada masing-masing $\mathrm{RW}$ yaitu terdapat $\mathrm{KK}$ yang tidak melakukan tindakan PSN DBD dirumahnya seperti di RW 1 sebanyak $1 \mathrm{KK}, \mathrm{RW} 2$ sebanyak $1 \mathrm{KK}$ dan RW 11 sebanyak 1 KK. Kurangnya pengetahuan responden mengenai PSN DBD dan rasa tidak mau melakukan adalah alasan tidak dilakukannya PSN DBD dengan cara $3 \mathrm{M}$ plus.

b. Gerakan 3M Plus

1) Menguras bak mandi seminggu sekali Survei mengenai praktik menguras bak mandi seminggu sekali mendapatkan hasil secara keseluruhan di Kelurahan Karangpucung yaitu $59 \mathrm{KK}$ telah melakukannya dari total $69 \mathrm{KK}$ yang mempunyai bak mandi dengan persentase sebesar $86 \%$. Sejumlah $10 \mathrm{KK}$ dengan persentase sebesar $14 \%$ tidak menguras bak mandi seminggu sekali, sehingga terdapat kemungkinan bak mandi menjadi tempat perindukan nyamuk Aedes sp.

Praktik menguras bak mandi seminggu sekali pada masing-masing RW semua responden yang disurvei melakukan praktik tersebut (100\%) yaitu RW 3, RW 4, RW 5, RW 6, RW 7, RW 9, RW 10, RW 11 dan RW 12. Responden yang melakukan praktik tersebut telah mempunyai kesadaran bahwa bak mandi dapat menjadi tempat perindukan jentik nyamuk. Pengurasan bak mandi seminggu sekali dapat mengurangi risiko menjadi tempat perkembangbiakan nyamuk. Pengurasan setiap seminggu membuat nyamuk tidak akan berubah menjadi nyamuk dewasa, jika nyamuk bertelur pada hari kesatu dan dilakukan pengurasan pada hari ketujuh maka kondisi nyamuk masih dalam perkembangan jentik nyamuk atau ada yang sudah berubah menjadi pupa. Menurut DIT. JEN PP dan PL (2007b, h.7), perkembangbiakan dari telur sampai menjadi nyamuk dewasa kurang lebih 9-10 hari.

Responden di RW 1, RW 2, RW 8 masih ada yang tidak melakukan praktik menguras bak mandi 
seminggu sekali. Praktik menguras bak mandi yang paling rendah yaitu di RW 2 (29\%). Sebagian responden sudah terbiasa tidak menguras bak mandi seminggu sekali, namun menunggu hingga air sudah kotor atau keruh baru dilakukan pengurasan. Praktik menguras bak mandi yang tidak tepat juga dapat tidak menyelesaikan masalah, karena air yang dikuras akan mengalir ke pembuangan seperti selokan sehingga jentik akan tetap hidup dan akan berkembang menjadi nyamuk dewasa. Menguras bak mandi tepat dengan cara menyaring jentik di bak mandi, jentik yang tersaring tersebut disiram air panas atau dijemur di bawah sinar matahari sehingga jentik nyamuk dapat mati.

2) Menutup tempat penampungan air Praktik menutup tempat penampungan air (tempayan, gentong, drum atau sejenisnya) telah dilakukan oleh $62 \mathrm{KK}$ dari $68 \mathrm{KK}$ yang mempunyai tempat penampungan air dengan persentase $91 \%$. Sejumlah 6 KK dengan presentase 9\% tidak menutup tempat penampungan air, sehingga ada kemungkinan dapat menjadi tempat perindukan nyamuk Aedes sp.

Praktik menutup Tempat Penampungan Air (TPA) seperti tempayan, gentong, drum atau sejenisnya telah dilakukan oleh seluruh responden yang disurvei di RW 4, RW 5, RW 6, RW 7, RW 8, RW 10, RW 11 dan RW 12 sehingga risiko TPA menjadi perindukan nyamuk dapat berkurang. Sebagian responden di RW 1, RW 2, RW 3, RW 9 dan 12 tidak menutup TPA. Praktik menutup TPA yang paling rendah yaitu di RW 12 (50\%). TPA yang terbuka dapat memungkinkan menjadi tempat perindukan nyamuk, karena nyamuk mencari tempat yang jauh dari predator untuk bertelur dan nyamuk Aedes $s p$ menyukai air bersih untuk tempat bertelur.

3) Mengubur atau membersihkan pekarangan dari barang bekas

Praktik mengubur atau membersihkan pekarangan dari barang bekas dilakukan oleh $70 \mathrm{KK}$ dari $98 \mathrm{KK}$ yang telah disurvei dengan persentase $71 \%$ sehingga dapat mencegah tempat perindukan nyamuk di luar rumah seperti barang bekas seperti kaleng atau pecahan botol saat musim hujan. Sejumlah 28 KK dengan presentase 27\% tidak mengubur atau membersihkan pekarangan dari barang bekas, hal tersebut terbukti dengan banyaknya barang bekas di sekitar rumah responden saat disurvei.

Praktik mengubur atau membersihkan pekarangan dari barang bekas dilakukan oleh seluruh responden di RW 3, RW 4, RW 5, RW 6, RW 7, RW 8, RW 9, RW 10, RW 11, dan RW 12. Responden yang melakukan praktik tersebut telah memiliki kesadaran mengenai kebersihan lingkungan. RW 1 dan RW 2 tidak ada yang melaksanakan praktik tersebut $(0 \%)$. Keberadaan barang bekas di sekitar rumah berisiko terdapatnya tempat perindukan nyamuk di luar rumah menjadi besar saat musim hujan tiba, karena adanya genangan air hujan di dalam wadah bekas tempat minuman atau pecahan botol.

4) Menutup lubang pada potongan bambu/pohon

Praktik menutup lubang pada potongan bambu/pohon sebanyak 16 KK melaksanakannya dari $30 \mathrm{KK}$ yang disurvei dengan persentase $53 \%$. Sejumlah 14 KK dengan presentase $57 \%$ tidak melakukan praktik tersebut, hal itu dapat berisiko menjadi tempat perindukan nyamuk.

Praktik menutup lubang pada potongan bambu/pohon telah dilakukan oleh sebagian responden di RW 3, RW 4, RW 5, RW 7, RW 9 dan RW 10. Responden yang telah melakukan praktik tersebut, menutup lubang pada batang pohon dengan menggunakan tanah atau krikil. RW yang tidak melakukan praktik menutup lubang pada potongan bambu/pohon dari KK yang disurvei (0\%) yaitu RW 1, RW 2, RW, RW 8, RW 11 dan RW 12. Jumlah dari masyarakat yang melakukan praktik ini masih sedikit karena kurangnya pemahaman mengenai pentingnya menutup lubang pohon yang berlubang agar tidak menjadi tempat penampungan air alami sehingga 
dapat berpotensi menjadi perindukan nyamuk.

5) Mengganti air vas bunga seminggu sekali

Praktik mengganti air pada vas bunga seminggu sekali di Kelurahan Karangpucung sebanyak $10 \mathrm{KK}$ melakukannya dari $10 \mathrm{KK}$ yang mempunyai vas bunga dengan persentase $100 \%$. Masyarakat yang disurvei telah memiliki kesadaran untuk mengganti air pada vas bunga seminggu sekali.

Praktik mengganti air pada vas bunga seminggu sekali telah dilakukan seluruh responden yang mempunyai vas bunga dirumahnya yaitu RW 1, RW 3, RW 4, RW 7, RW 9 dan RW 10. Praktik tersebut telah dilakukan masyarakat sehingga mengurangi risiko vas bunga yang terdapat air di dalamnya menjadi tempat perindukan nyamuk. Nyamuk akan mencari tempat perindukan yang aman dari predator dan vas bunga sangat sesuai sebagai tempat perindukan nyamuk Aedes aegypti karena nyamuk suka bertelur di genangan air yang tertampung disuatu wadah terbuka, terlindung dari sinar matahari.

6) Membersihkan tempat minum burung seminggu sekali

Praktik membersihkan tempat minum burung seminggu sekali dilakukan oleh $27 \mathrm{KK}$ dari $27 \mathrm{KK}$ yang memelihara burung dirumahnya dengan persentase $100 \%$, sehingga mengurangi risiko nyamuk bertelur ditempat tersebut

Praktik membersihkan tempat minum burung seminggu sekali telah dilakukan oleh semua responden yang mememelihara burung dirumahnya yaitu di RW 1, RW 2, RW 3, RW 4, RW 5, RW 6, RW 7, RW 8, RW 9 dan RW 10. Praktik tersebut dilakukan masyarakat agar tempat minum burung tetap bersih, sehingga tempat minum burung tidak menjadi perindukan nyamuk.

7) Menggunakan obat nyamuk

Praktik menggunakan obat nyamuk dilakukan oleh $65 \mathrm{KK}$ dari total $98 \mathrm{KK}$ yang di survei dengan persentase $66 \%$, penggunaan obat nyamuk dapat mencegah gigitan nyamuk ketubuh sehingga dapat mengurangi risiko terjangkitnya penyakit DBD. Sejumlah $33 \mathrm{KK}$ dengan presentase $34 \%$ tidak menggunaan obat nyamuk.

Penggunaan obat nyamuk dilakukan oleh sebagian masyarakat yang menjadi responden di RW 1 sampai RW 12. Praktik penggunaan obat nyamuk yang paling rendah yaitu di RW 10 (20\%). Tidak semua responden melakukan praktik tersebut dengan alasan penggunakan obat nyamuk tidak praktis dan kurang nyaman jika digunakan. Penggunaan obat nyamuk adalah salah satu cara untuk mencegah gigitan nyamuk sehingga risiko terkena penyakit DBD melalui gigitan nyamuk Aedes $s p$ menjadi berkurang.

8) Tidur menggunakan kelambu

Tidur menggunakan kelambu pada masyarakat yang disurvei di Kelurahan Karangpucung menunjukkan sebanyak 4 KK melakukannya dari $98 \quad \mathrm{KK}$ yang disurvei dengan persentase $4 \%$. Penggunaan kelambu ini masih sedikit yang mau menggunakannya.

Penggunaan kelambu pada responden di $12 \mathrm{RW}$ dapat diketahui bahwa seluruh masyarakat yang disurvei tidak menggunakan kelambu (0\%) yaitu di RW 1, RW 2, RW 3, RW 5, RW 6, RW 9, RW 10, RW 12. Jumlah masyarakat yang menggunakan kelambu tergolong sedikit, karena masyarakat merasa tidak nyaman apabila menggunakan kelambu, tidak praktis dan harganya yang mahal. Penggunaan kelambu dapat mencegah gigitan nyamuk dan dapat mengurangi risiko terkena penyakit DBD melalui gigitan nyamuk Aedes sp.

9) Menggunakan kawat kasa pada lubang ventilasi

Praktik menggunakan kawat kasa pada lubang ventilasi pada seluruh responden di Kelurahan Karangpucung dilakukan sebanyak 12 $\mathrm{KK}$ dari $98 \mathrm{KK}$ yang telah disurvei dengan persentase $12 \%$.

Penggunaan kawat kasa pada lubang ventilasi dilakukan oleh sebagian responden di RW 1, RW 4, RW 5, RW 6, RW 9, RW 11, RW 12. Jumlah masyarakat yang menggunakan kawat kasa masih 
sedikit, karena kurangnya pemahaman mengenai manfaat penggunaan kawat kasa pada lubang ventilasi dapat mencegah nyamuk dapat masuk ke dalam rumah. Cara tersebut dapat mengurangi kemungkinan nyamuk dapat masuk ke dalam rumah sehingga mengurangi risiko terkena penyakit DBD melalui gigitan nyamuk.

10) Menaburi abate 3 bulan sekali pada tempat penampungan air yang jarang dikuras

Praktik menaburi abate 3 bulan sekali pada tempat penampungan air yang jarang dikuras sebanyak $17 \mathrm{KK}$ melakukannya dari 98 KK yang mempunyai tempat penampungan air dengan persentase $17 \%$. Pemakaian abate masih sedikit digunakan oleh masyarakat, bagi sebagian masyarakat yang disurvei belum memahami mengenai abate. Penggunaan abate pada tempat penampungan air yang jarang dikuras dapat membunuh jentik nyamuk dan mencegah adanya jentik nyamuk selama 3 bulan, karena menurut Dirjen PP dan PL (2007b, h.15) abate akan menempel pada dinding tempat penampungan air dan bertahan hingga 3 bulan.

Praktik penaburan abate 3 bulan sekali pada tempat penampungan air yang jarang dikuras dilakukan oleh sebagian responden di RW 1, RW 3, RW 4, RW 5, RW 6, RW 7, RW 8, RW 9, dan RW 11. Penggunaan abate yang paling rendah $(0 \%)$ di RW 2, RW 10 dan RW 12. Praktik abatisasi tersebut bagi masyarakat yang telah melakukannya terdapat kendala karena sebagian dari masyarakat tidak mengetahui tempat yang menjual abate sehingga menggantungkan pembelian abate kepada penjual keliling, sedangkan penjual tersebut tidak selalu berjualan. Upaya abatisasi sudah di informasikan kepada masyarakat namun belum semua masyarakat memahami dan mau melakukannya sehingga masyarakat yang melakukan praktik tersebut jumlahnya sedikit.

11) Memelihara ikan pemakan jentik

Praktik memelihara ikan pemakan jentik sebanyak 6 KK dari 98 KK yang disurvei dengan persentase $6 \%$. Sebagian masyarakat yang telah mengetahui pemeliharaan ikan pemakan jentik seperti ikan sepat dapat memakan jentik nyamuk, ikan tersebut diletakan ke dalam sumur mereka kemudian jenis ikan lainnya seperti ikan nila ada yang meletakannya di dalam kolam ikan. Praktik tersebut masih kurang diinformasikan kepada masyarakat sehingga masih banyak masyarakat yang belum mengetahui manfaat pemeliharaan ikan pemakan jentik untuk mengurangi kepadatan jentik nyamuk.

Pemeliharaan ikan pemakan jentik dilakukan oleh sebagian masyarakat yang disurvei di RW 4, RW 6, RW 9 dan RW 11. Jumlah masyarakat yang memelihara ikan pemakan jentik masih sedikit karena kurangnya pemahaman mengenai ikan pemakan jentik dapat sebagai predator yang memakan jentik nyamuk.

12) Tidak menggantungkan pakaian di dalam rumah

Praktik tidak menggantungkan pakaian di dalam rumah sebanyak 29 KK melakukannya dari $98 \mathrm{KK}$ yang disurvei dengan persentase $30 \%$. Praktik tersebut masih sedikit masyarakat yang melakukannya.

Praktik tidak mengggantungkan pakaian di dalam rumah dilakukan oleh sebagian responden pada semua RW yang disurvei. RW 7 paling rendah praktik tidak mengggantungkan pakaian di dalam rumah (9\%). Kurangnya pemahaman bahwa pakaian yang digantung di dalam rumah dapat memungkinkan menjadi resting nyamuk dan faktor kebiasaan menggantungkan pakaian yang sudah dipakai di dalam rumah yang sulit untuk dirubah. Gantungan pakaian yang berada di belakang pintu kamar adalah tempat yang disukai nyamuk untuk hinggap. Menurut Dirjen PP dan PL (2007a, h.28), tempat-tempat yang disenangi nyamuk untuk hinggap atau istirahat selama menunggu waktu bertelur adalah tempat-tempat yang gelap, lembab dan sedikit angin. 
13) Memperbaiki talang air yang rusak

Praktik memperbaiki talang air yang rusak dilakukan oleh $82 \mathrm{KK}$ dari 98 KK yang disurvei dengan persentase $84 \%$. Praktik tersebut sudah banyak dilakukan oleh masyarakat.

Praktik memperbaiki talang air yang rusak dilakukan oleh sebagian masyarakat di semua RW yang disurvei. RW 1 paling rendah praktik memperbaiki talang air yang rusak (27\%). Praktik ini banyak dilakukan masyarakat agar aliran air dapat lancar. Aliran air yang tidak lancar sehingga menggenang pada talang air dapat menjadi tempat perindukan nyamuk.

Berdasarkan hasil survei pelaksanaan PSN DBD terdapat urutan masalah yang nilainya masih rendah yaitu sebagai berikut:

a. Tidur menggunakan kelambu (4\%).

Praktik ini masih rendah dilakukan oleh masyarakat, karena jarang ada masyarakat yang menggunakan kelambu sekarang. Masyarakat menganggap penggunaan kelambu tidak praktis dan tidak nyaman selain itu harganya yang mahal.

b. Memelihara ikan pemakan jentik (6\%)

Sosialisasi mengenai manfaat ikan pemakan jentik yang kurang membuat masyarakat banyak yang tidak mengetahui manfaat pemeliharaan ikan pemakan jentik sebagai predator jentik nyamuk, sehingga pemeliharaan ikan pemakan jentik sangat sedikit jumlahnya dimasyarakat.

c. Penggunaan kawat kasa pada lubang ventilasi $(12 \%)$

Masyarakat kurang mengetahui bahwa kawat kasa pada lubang ventilasi dapat membantu mencegah nyamuk masuk ke dalam rumah melalui ventilasi, sehingga kebanyakan dari masyarakat tidak menggunakan kawat kasa pada lubang ventilasinya.

d. Penaburan abate (17\%)

Sosialisasi mengenai penggunaan abate sudah dilakukan di Kelurahan Karangpucung, pembagian abate secara gratis juga sudah dilakukan. Kebanyakan masyarakat masih tidak mau menggunakan abate karena menganggap penggunaannya yang tidak praktis. Sebagian masyarakat yang pernah menggunakannya terdapat kendala karena tidak mengetahui penjualan abate, sehingga penggunaannya terhenti.

Pelaksanaan PSN DBD dari hasil survei pada seluruh item kuesioner RW yang paling rendah adalah RW 2 (29\%) dan RW 1(39\%). Pelaksanaan PSN DBD yang kurang baik seperti di RW 2 membuat banyaknya container yang positif jentik nyamuk, sehingga dapat membuat potensi penularan DBD menjadi tinggi. Hasil survei jentik menunjukkan RW 2 yang paling rendah ABJ $(50 \%), \mathrm{HI}$ paling tinggi $(50 \%), \mathrm{Cl}$ paling tinggi (15\%), dan $\mathrm{BI}$ paling tinggi $(50 \%)$, selain itu terdapat kasus DBD di RW 2 (1 kasus). RW 1 tidak ada kasus DBD, namun pelaksanaan PSN DBD yang rendah dapat memungkinkan terdapat tempat perindukan nyamuk sesuai dengan hasil survei jentik RW 1 ditemukan container yang positif jentk nyamuk.

Pelaksanaan PSN DBD yang paling tinggi atau baik di RW 9 (66\%) dan RW 7 (63\%). Pelaksanaan PSN DBD yang baik dapat mengurangi perindukan nyamuk dan mengurangi kepadatan vektor, sehingga kasus DBD dapat berkurang. Sesuai dengan hasil survei jentik yang menunjukkan RW 7 dan 9 paling baik ABJ (100\%), $\mathrm{HI}(0 \%), \mathrm{Cl}(0 \%)$ dan $\mathrm{BI}$ (0\%).

2. Perhitungan Angka Bebas Jentik (ABJ), House Index (HI), Container Index (Cl), dan Breteu Index (BI) di Kelurahan Karangpucung.

Berdasarkan survei dapat diketahui bahwa dari 98 sampel rumah yang diperiksa di Kelurahan Karangpucung, 21 rumah positif jentik nyamuk dan 23 container positif jentik nyamuk dari 528 container yang diperiksa. Container yang paling banyak positif jentik nyamuk yaitu di bak mandi dan pot bunga. Bak mandi menjadi tempat bertelur yang disukai nyamuk Aedes sp karena telur nyamuk menempel pada dinding yang kasar seperti bak mandi. Pot bunga yang positif jentik saat disurvei dalam kondisi terdapat genangan air, karena bagian bawah tidak ada lubang keluarnya air sehingga air menggenang pada pot. Kondisi tersebut dapat menjadi tempat perindukan nyamuk diluar rumah. 
Perhitungan mengenai $\mathrm{ABJ}, \mathrm{HI}, \mathrm{Cl}$ dan $\mathrm{BI}$ pada seluruh sampel di Kelurahan Karangpucung yaitu Angka Bebas Jentik (ABJ) sebesar $79 \%$, hasil perhitungan tersebut menunjukkan persentase rumah yang tidak ditemukan jentik masih $79 \%$. Hasil perhitungan House Index $(\mathrm{HI})$ yaitu sebesar $21 \%, \mathrm{HI}$ tersebut menunjukkan persentase rumah/ tempat yang positif jentik Aedes $s p$ dari seluruh rumah/tempat yang diperiksa sebesar $21 \%$. Container Index (Cl) sebesar 5\%, hal tersebut menunjukkan persentase container yang positif jentik Aedes spp dari seluruh container yang diperiksa sebesar $5 \%$. Breteu Index (BI) sebesar 23\%, hal tersebut menunjukkan jumlah container yang positif jentik dari seluruh rumah yang diperiksa rumah dengan persentase sebesar $23 \%$.

Hasil survei jentik disetiap RW di Kelurahan Karangpucung dengan jumlah 12 RW adalah sebagai berikut:

a. Angka Bebas Jentik (ABJ)

Hasil perhitungan Angka Bebas Jentik (ABJ) yang belum mencapai 95\% sehingga memiliki potensi penularan DBD besar yaitu di RW 1 sebesar $82 \%$, RW 2 sebesar $50 \%$, RW 3 sebesar $86 \%$, RW 4 sebesar $50 \%$, RW 5 sebesar 86\%, RW 6 sebesar 90\%, RW 10 sebesar 80\%, RW 11 sebesar $71 \%$ dan RW 12 sebesar $75 \%$.

b. House Index (HI)

Hasil perhitungan House Index $(\mathrm{HI})$ yang masih tinggi $\mathrm{HI} \geq 10 \%$ yaitu di RW 1 sebesar $18 \%$, RW 2 sebesar $50 \%$, RW 3 sebesar 14\%, RW 4 sebesar $50 \%$, RW 5 sebesar $14 \%$, RW 6 sebesar $10 \%$, RW 8 sebesar $27 \%$, RW 10 sebesar 20\%, RW 11 sebesar $29 \%$, RW 12 sebesar $25 \%$.

c. Container Index (Cl)

Hasil perhitungan Container Index (Cl) yang masih tinggi $\mathrm{Cl} \geq 5 \%$ yaitu di RW 2 sebesar $15 \%$, RW 4 sebesar $8 \%$, RW 8 sebesar $6 \%$, RW 10 sebesar $5 \%$, RW 11 sebesar 8\%, RW 12 sebesar $6 \%$

d. Breteu Index (BI)

Hasil perhitungan Breteu Index (BI) yang masih tinggi $\mathrm{BI}>50 \%$ berada di RW 2 sebesar $50 \%$ dan RW 4 sebesar $50 \%$.

Hasil perhitungan mengenai $A B J, H I$, $\mathrm{Cl}$ dan $\mathrm{BI}$ menunjukkan bahwa daerah Kelurahan Karangpucung masih banyak jentik nyamuk yang ditemukan pada berbagai jenis container di dalam rumah maupun di luar rumah. PSN DBD yang berjalan kurang maksimal dilakukan, karena belum semua masyarakat berperan aktif dalam pelaksanaannya. Berdasarkan hasil tersebut terdapat kemungkinan penularan DBD karena masih banyaknya tempat perindukan nyamuk.

3. Membandingkan Angka Bebas Jentik (ABJ), House Index (HI), Container Index (CI) dan Breteu Index (BI) dengan standar atau peraturan yang berlaku.

Standar kepadatan jentik yang digunakan di Indonesia adalah Angka Bebas Jentik (ABJ). ABJ di Kelurahan Karangpucung sebesar 79\%, apabila dibandingan dengan standar dari Depkes RI tidak memenuhi syarat karena ABJ belum mencapai $95 \%$ sehingga PSN DBD belum belum berhasil. Menurut Depkes RI Dirjen PPM-PLP (1995, h.4), sasaran gerakan PSN DBD dapat diukur dengan tercapainya $A B J \geq 95 \%$ di Kecamatan endemis dan sporadis.

Hasil perhitungan House Index $(\mathrm{HI}) \mathrm{di}$ Kelurahan Karangpucung sebesar $21 \%$, $\mathrm{HI}$ tersebut tidak memenuhi syarat bila dibandingkan dengan peraturan $\mathrm{WHO}$ karena $\mathrm{HI} \geq 10 \%$. $\mathrm{HI}$ tersebut menunjukkan daerah Kelurahan Karangpucung mempunyai kepadatan dan penyebaran vektor yang tinggi, karena menurut $\mathrm{WHO}$ (2007, h.34) suatu daerah dikatakan mempunyai kepadatan dan penyebaran vektor yang tinggi jika nilai $\mathrm{HI} \geq 10 \%$.

Hasil perhitungan Container Index (Cl) di Kelurahan Karangpucung sebesar 5\%, apabila dibandingkan dengan standar peraturan WHO tidak memenuhi syarat karena $\mathrm{Cl} \geq 5 \%$. $\mathrm{Cl}$ tersebut menunjukkan bahwa daerah Kelurahan Karangpucung masih mempunyai kepadatan dan penyebaran vektor yang tinggi untuk penularan DBD, karena menurut WHO (2007, h.34) suatu daerah dikatakan mempunyai kepadatan dan penyebaran vektor yang tinggi untuk penularan DBD jika nilai $\mathrm{Cl} \geq 5 \%$.

Hasil perhitungan Breteu Index (BI) di Kelurahan Karangpucung sebesar 23\%, apabila dibandingan dengan standar peraturan WHO memenuhi syarat karena $\mathrm{BI}<50 \%$. Jumlah container positif jentik masih memenuhi standar dari seluruh rumah yang diperiksa.

Hasil perhitungan $\mathrm{ABJ}, \mathrm{HI}, \mathrm{Cl}$ dan $\mathrm{BI}$ pada 12 RW di Kelurahan Karangpucung 
dibandingkan standar peraturan $\mathrm{WHO}$ dapat dijabarkan seperti berikut:

a. Angka Bebas Jentik (ABJ)

Angka Bebas Jentik (ABJ) di RW 7 dan RW 9 memenuhi syarat karena $A B J \geq 95 \%$, hal tersebut sesuai dengan hasil survei mengenai pelaksanaan PSN DBD yang menunjukkan RW 7 dan 9 paling baik dalam pelaksanaan PSN DBD. RW yang ABJ paling rendah berada di RW 2 dan RW 4 (50\%), hal tersebut didukung oleh jumlah penderita DBD tahun 2013 banyak ditemukan di RW 4 (5 penderita) dan RW 2 (1 penderita). Berdasarkan hasil survei pelaksanaan PSN DBD RW 2 paling buruk pelaksanaan PSN DBD (29\%). RW 4 termasuk urutan ketiga terbaik pelaksanaan PSN DBD (62\%), namun partisipasi masyarakat belum seluruhnya melaksanakan PSN DBD sehingga membuat $A B J$ menjadi rendah.

b. House Index (HI)

House Index (HI) RW 7 dan 9 memenuhi standar peraturan WHO karena $\mathrm{HI}<10 \%$, hal tersebut menunjukkan rumah/tempat yang positif jentik Aedes spp dari seluruh rumah/tempat yang diperiksa di RW tersebut. $\mathrm{HI}$ yang paling rendah di RW 7 dan RW 9 (0\%), hal tersebut disukung dengan hasil survei pelaksanaan PSN DBD yang menunjukkan RW 7 dan RW 9 yang paling baik pelaksanaan PSN DBD. HI paling tinggi berada di RW 2 dan RW 4 $(50 \%)$, hal itu menunjukkan RW tersebut mempunyai kepadatan dan penyebaran vektor yang tinggi, sehingga jumlah kasus DBD di RW 4 yang paling tinggi kasusnya (5 kasus) dan RW 2 (1 kasus). RW 2 terdapat 1 kasus, hal tersebut dapat karena penyebab lain seperti mobilitas penduduk sehingga diperlukan penelitian lebih lanjut mengenai kasus DBD dengan penyelidikan epidemiologi.

c. Container Index (Cl) Container Index (Cl) di RW 1, RW 3, RW 5, RW 6, RW 7, RW 9 memenuhi syarat standar WHO karena $\mathrm{Cl}<5 \%$. Cl yang paling rendah di RW 7 dan RW 9. Container Index $(\mathrm{Cl})$ di RW 2, RW 4, RW 8, RW 10, RW 11, RW 12 tidak memenuhi syarat karena $\mathrm{Cl} \geq 5 \%$. RW yang $\mathrm{Cl}$ paling tinggi berada di RW 2 (15\%), RW 4 (8\%) dan RW 11 (8\%), sehingga mempunyai kepadatan dan penyebaran vektor yang tinggi untuk penularan DBD. Berdasarkan hasil survei pelaksanaan PSN DBD RW 2 termasuk yang paling buruk pelaksanaannya dan terdapat 1 kasus DBD. RW 4 adalah RW yang mempunyai kasus tertinggi DBD (5 kasus). RW 11 tidak ada kasus DBD namun dengan $\mathrm{Cl}$ yang tinggi dapat berpotensi memiliki penyebaran vektor yang tinggi di wilayah tersebut.

d. Breteu Index (BI)

Breteu Index (BI) di RW 1, RW 3, RW 5, RW 6, RW 7, RW 8, RW 9, RW 10, RW 11, RW 12 memenuhi syarat karena $\mathrm{BI}<50 \%$. BI yang paling rendah di RW 7 dan RW 9, sehingga sebaran rumah termasuk kecil dalam mempengaruhi sebaran transmisi penyakit DBD. RW yang $\mathrm{BI}$ telah memenuhi syarat sudah banyak jumlahnya. Breteu Index (BI) di RW 2 dan RW 4 tidak memenuhi syarat karena $\mathrm{BI}>50 \%$, sehingga sebaran rumah besar dalam mempengaruhi sebaran transmisi penyakit DBD. Hal tersebut terbukti dengan jumlah kasus DBD yang paling tinggi di wilayah Kelurahan Karangpucung adalah di RW 4 (5 kasus DBD), sedangkan di RW 2 terdapat kasus DBD sebanyak 1 kasus.

\section{SIMPULAN DAN SARAN}

\section{A. Simpulan}

1. Pelaksanaan Pemberantasan Sarang Nyamuk (PSN) Demam Berdarah Dengue (DBD) di Kelurahan Karangpucung dari hasil survei menunjukkan bahwa PSN DBD yang paling tinggi atau baik di RW 9 (66\%) dan RW 7 (63\%), sedangkan yang paling rendah atau buruk di RW 2 (29\%) dan RW 1 (39\%) .

2. Praktik gerakan $3 \mathrm{M}$ plus di Kelurahan Karangpucung yang menjadi masalah karena presentasenya yang rendah dari hasil survei adalah berikut:

a. Tidur menggunakan kelambu (4\%).

b. Memelihara ikan pemakan jentik (6\%)

c. Penggunaan kawat kasa pada lubang ventilasi $(12 \%)$

d. Penaburan abate (17\%)

3. Perhitungan Angka Bebas Jentik (ABJ), House Index $(\mathrm{HI})$, Container Index $(\mathrm{Cl})$, dan Breteu Index (BI) di Kelurahan 
Karangpucung yaitu ABJ sebesar 79\%, HI yaitu sebesar 21\%, $\mathrm{Cl}$ sebesar $5 \%$, BI sebesar $23 \%$.

4. ABJ di Kelurahan Karangpucung sebesar $79 \%$, tidak memenuhi syarat (ABJ < 95\%). $\mathrm{HI}$ sebesar $21 \%$ tidak memenuhi syarat karena $\mathrm{HI} \geq 10 \%$. $\mathrm{Cl}$ sebesar $5 \%$, tidak memenuhi syarat karena $\mathrm{Cl} \geq 5 \%$. BI sebesar $23 \%$ memenuhi syarat karena $\mathrm{BI}$ $<50 \%$. RW 2 dan 4 memiliki ABJ paling rendah (50\%), HI paling tinggi di RW 2 dan 4 (50\%), Cl paling tinggi di RW 2 (15\%), RW 4 (8\%) dan 11 (8\%), BI paling tinggi di RW 2 dan 4 (50\%).

\section{B. Saran}

1. Bagi Dinas Kesehatan Kabupaten Banyumas

Dinas Kesehatan Kabupaten

Banyumas sebaiknya selalu menggalakan PSN DBD di seluruh wilayah Banyumas agar kasus DBD dapat berkurang jumlahnya.

2. Bagi Kader PSN DBD

Seluruh kader PSN DBD di Kelurahan Karangpucung sebaiknya lebih diaktifkan lagi agar kader yang ada di setiap RW dapat menggerakan masyarakat untuk melakukan PSN DBD dengan gerakan 3M plus di wilayahnya.

3. Bagi masyarakat

a. Masyarakat di RW 1,2 dan 4 sebaiknya lebih meningkatkan partisipasi untuk melakukan PSN DBD agar kepadatan jentik nyamuk di RW tersebut dapat berkurang jumlahnya, sehingga dapat mengurangi kasus DBD.

b. Praktik menguras bak mandi sebaiknya dilakukan secara tepat dengan cara menyaring jentik pada lubang bagian bawah bak mandi dan membersihkan bagian pinggir dinding bak mandi agar telur yang menempel di pinggir dinding dapat terkuras. Jentik yang tersaring tersebut disiram air panas atau dijemur di bawah sinar matahari sehingga jentik nyamuk dapat mati.

4. Bagi Peneliti Lain

Sebaiknya untuk peneliti berikutnya dapat melakukan penelitian lanjutan mengenai kejadian DBD di Kelurahan Karangpucung dengan penelitian kasus DBD melalui penyelidikan epidemiologi.

\section{DAFTAR PUSTAKA}

Birowo Hardi Waluyoko, 2013, Kecamatan Purwokerto Selatan Dalam Angka 2013, Purwokerto: Badan Pusat Statistik Kabupaten Banyumas

Buletin Jendela Epidemiologi, 2010, "Demam Berdarah Dengue", Jakarta : Pusat Data dan Survailans Epidemiologi Kementerian Kesehatan RI Vol.2

Cecep Dani Sucipto, 2011, Vektor Penyakit Tropis, Yogyakarta: Gosyen Publishing

Dantji T. Sembel, 2009, Entomologi Kedokteran, Yogyakarta : CV ANDI OFFSET

Depkes RI, 1995, Menuju Desa Bebas Demam Berdarah Dengue, Jakarta: Dirjen PPM \& PL.

), 2009, Rencana Pembangunan Jangka Panjang Bidang Kesehatan, Jakarta : Departemen Kesehatan RI

Departemen Kesehatan R.I. Direktorat Jenderal Pengendalian Penyakit dan Penyehatan Lingkungan (DIR.JEN.PP\&PL), 2007a, Ekologi dan Aspek Perilaku Vektor, Jakarta: DIT.JEN. PP \& PL

), 2007b, Pemberantasan Sarang Nyamuk Demam Berdarah Dengue (PSN $D B D)$ oleh Jumantik, Jakarta: DIT.JEN. PP $\& P L$

), 2007c, Survai Entomologi Demam Berdarah Dengue, Jakarta: DIT.JEN. PP \& $\mathrm{PL}$

Dinas Kesehatan Kabupaten Banyumas, 2013, Laporan Kasus Demam Berdarah Dengue Tahun 2013, Purwokerto: Dinas Kesehatan Kabupaten Banyumas

Dirjen PPM dan PLP, 1992, Petunjuk Teknis Pemberantasan Nyamuk Penular Penyakit Demam Berdarah Dengue, Jakarta: Depkes RI

Ditjen PP \& PL Depkes RI, 2008, Persentase Kasus DBD Berdasarkan Jenis Kelamin Tahun 2008, Jakarta: Buletin Jendela Epidemiologi Pusat Data dan Survailans Epidemiologi Kementerian Kesehatan RI Vol.2 
Kelurahan Karangpucung, 2014, Profil Kelurahan Karangpucung, Purwokerto: Kelurahan Karangpucung

Kemenkes Indonesia, 2013, "Masih Endemis Demam Berdarah" http://www.tempo.co/read/news/2013/07/2 6/173500085 diakses tanggal 4 November 2013, pukul pukul 15.28 WIB.

Nunung Cahyanto Setyawan, 2010, Tinjauan Pelaksanaan Program Pemberantasan Vektor Penyakit Demam Berdarah Dengue (DBD) di Wilayah Kerja Puskesmas 1 Cilacap Utara Kabupaten Cilacap Tahun 2010, Purwokerto : Jurusan Kesehatan Lingkungan, Politeknik Kesehatan Kemenkes Semarang.

Primal Sudjana, 2010, Diagnosis Dini Penderita Demam Berdarah Dengue Dewasa, Jakarta : Buletin Jendela Epidemiologi Pusat Data dan Survailans Epidemiologi Kementerian Kesehatan RI Vol.2

Puskesmas Purwokerto Selatan, 2013, Laporan Kasus Demam Berdarah Dengue Dari Tahun 2009-2013, Purwokerto: Puskesmas Purwokerto Selatan

Rio Pamungkas, 2011, "Perbandingan Keefektifan Antara Ikan Cupang (Ctenops vittatus) Dan Ikan Nila (Oreochromis niloticus) Dalam Memakan jentik Nyamuk Aedes aegypti" , Semarang : UNNES, http://JURNAL/perbandingan-keefektifanantara-ikan.html diakses tanggal 8 Februari 2014 pukul 14.00 WIB

Ririh Yudhastuti, 2011, Pengendalian Vektor dan Rodent, Surabaya: Pustaka Melati

Sari, Cut, I, N, 2005, "Pengaruh Lingkungan Terhadap Perkembangan Penyakit Malaria dan Demam Berdarah Dengue", http://www.rudyct.com/PPS702ipb/09145/cut irsanya ns.pdf diakses 9 Februari 2014 pukul 21.35 WIB
Soegeng Soegijanto, 2008, Demam Berdarah Dengue Edisi 2, Surabaya: Airlangga University Press.

Sri Wahyuni, 2013, Monitoring Dan Evaluasi Kegiatan Survey Jentik Aedes aegypti Di Desa Pliken Kecamatan Kembaran Kabupaten Banyumas Tahun 2011-2012, Purwokerto: Jurusan Kesehatan Lingkungan, Politeknik Kesehatan Kemenkes Semarang.

Supratman Sukowati, 2010, "Masalah Vektor Demam Berdarah Dengue (DBD) dan Pengendaliannya di Indonesia“ , Jakarta: Buletin Jendela Epidemiologi Pusat Data dan Survailans Epidemilogi Kementerian Kesehatan RI Vol.2

Subdirektorat Arbovirosis, 2009, Database kasus DBD di Indonesia Tahun 1968 - 2009, Jakarta : Ditjen PP \& PL Kementerian Kesehatan RI

Tri Cahyono, 2014, Pedoman Penulisan Proposal Penelitian dan Karya Tulis IImiah/Skripsi (Edisi Revisi Ke Tiga), Purwokerto : Jurusan Kesehatan Lingkungan Purwokerto.

Tri Yunis Miko Wahyono, dkk, 2010, "Faktorfaktor Yang Berhubungan Dengan Kejadian Demam Berdarah Dan Upaya Penanggulangannya Di Kecamatan Cimanggis, Depok, Jawa Barat " , Jakarta : Buletin Jendela Epidemiologi Pusat Data dan Survailans Epidemiologi Kementerian Kesehatan RI Vol.2

WHO, 2007, Tren Dengue In Indonesia, Ganeva : World Health Organization

Widoyono, 2005, Epidemiologi, Penularan, Pencegahan dan Pemberantasan Penyakit Tropis, Jakarta : Erlangga.

Yulian Taviv, Akhmad Saikhu, Hotnia Sitorus, 2010, "Pengendalian DBD Melalui Pemanfaatan Pemantau Jentik dan Ikan Cupang di Kota Palembang", Jakarta : Buletin Litbang Depkes Vol: 38, No.4 